\title{
5. FINE-GRAINED TURBIDITES OF THE AMAZON FAN: FACIES CHARACTERIZATION AND INTERPRETATION ${ }^{1}$
}

\author{
David J.W. Piper² and Mark Deptuck ${ }^{2}$
}

\begin{abstract}
Much of the sediment thickness found on Amazon Fan levees is attributed to mud with silt laminae. The distribution of sharp-based graded beds and the distribution of bioturbation, diagenetic fronts, and nannofossils demonstrates that many of the beds were deposited rapidly and episodically. The total thickness of mud decreases sharply away from active channels. These observations suggest that most of the levees are built of fine-grained turbidites. Twelve facies of fine-grained turbidites are distinguished from visual core description, X-radiography, and grain-size analysis. Some facies appear diagnostic of particular fan settings. Modal grain size of both muds and thin silt laminae decreases downfan. Facies distribution is consistent with the progressive spillover of a turbidity current as it moves down the channel system.
\end{abstract}

\section{INTRODUCTION}

\section{Fine-Grained Turbidites}

Turbidity currents transport and deposit large volumes of finegrained sediment. Turbidites composed principally of mud (flocculated silt and clay) are probably volumetrically more abundant than turbidite sands, but they have been much less studied. Mud turbidites have fewer distinctive features than turbidites of sand and gravel, and they tend to be fissile or cleaved and poorly exposed in ancient rocks. Nevertheless, fine-grained turbidites contain important information on the nature of turbidity current flows (McCave and Jones, 1988; Kranck et al., 1996) and show facies variations with depositional environment that may be important in interpreting ancient basins.

Fine-grained turbidites correspond to the $T_{d}$ and $T_{e}$ divisions of the classic Bouma sequence in turbidites (Bouma, 1962) and are commonly graded from silt passing up into mud (Piper, 1978; Piper and Stow, 1991). Stow and Shanmugam (1980) recognized some 10 divisions in graded silt to mud turbidite beds, with individual beds commonly showing either base- or top-cut-out of many divisions. The origin of silt laminae in mud turbidites has been widely debated in the literature without any consensus emerging (Stow and Bowen, 1980; Hesse and Chough, 1980; Carey and Roy, 1985). Although Piper and Stow (1991) attempted a synthesis of scattered data from the literature, there is no well-established model of variation in finegrained turbidite facies with different deep-sea physiographic environments.

The middle and upper Amazon Fan consists of stacked channellevee systems in which levee sediments consist principally of muds with lesser interbedded silts and fine sands. Much of the deep-sea fan, therefore, is built of fine-grained sediments that we interpret as turbidites. Leg 155 sampled a range of levee environments, from crest to flank and from upper fan to lower fan. The purpose of this paper is to present evidence that much of the fine-grained sediment is of turbidite origin, to describe lithologic variation in fine-grained turbidite facies, and to interpret geographic variation in fine-grained turbidite facies.

${ }^{1}$ Flood, R.D., Piper, D.J.W., Klaus, A., and Peterson, L.C. (Eds.), 1997. Proc. ODP, Sci. Results, 155: College Station, TX (Ocean Drilling Program).

${ }^{2}$ Atlantic Geoscience Centre, Geological Survey of Canada (Atlantic), Bedford Institute of Oceanography, P.O. Box 1006, Dartmouth, N.S., B2Y 4A2 Canada. piper@agc.bio.ns.ca

\section{Geological Setting of the Amazon Fan}

The Amazon Fan (Fig. 1) is a typical large passive-margin muddy fan (Flood et al., 1991; Flood et al., 1995). The lower fan consists of sands deposited beyond the limit of any well-defined channel system. The middle and upper fan are traversed by a meandering channel that built high levees and periodically underwent avulsion. The term "Amazon Channel" is applied to the youngest channel-levee system; each older near-surface channel-levee system recognized in seismicreflection profiles has been given a color designation (Fig. 2). The Amazon and the preceding Brown Channel-levee Systems represent deposition since the last glacial maximum (LGM). The fan channel is inactive during extreme highstands of sea level, most recently in the mid to late Holocene. Individual channel-levee systems are grouped stratigraphically into levee complexes, with each levee complex corresponding to a major glacial lowstand of sea level of 50,000100,000 yr duration.

\section{Methods}

Fine-grained turbidites have important features on a scale of millimeters, finer than the normal level of detail for shipboard description of cores. Approximately 60 intervals of core, generally $30 \mathrm{~cm}$ long, were described millimeter by millimeter on the split core face aboard ship. A $15-\mathrm{cm}$ representative slab was taken from most intervals and X-radiographed. Core intervals were selected to represent the range of fine-grained turbidites recognized while splitting and describing core.

Many delicate sedimentary features were picked out in freshly split core faces by variations in the distribution of unstable iron sulfide minerals that oxidized within a few hours. Depending on the time elapsed between splitting and photography, core photographs show sedimentary features to varying degrees. Most of the features described aboard ship are no longer visible in the oxidized cores stored in the Bremen Core Repository.

Sediment slabs were subsampled for grain-size analysis by Coulter counter, smear slides, and impregnation for thin sectioning. Grain-size analyses were made on 3- $\mathrm{mm}^{3}$ samples using Coulter Counter model number TA II with sediment dispersed in a 5\% Calgon (sodium hexametaphosphate) electrolyte solution. Samples were disaggregated by ultrasound. Replicate analyses showed that neither variations in the amount of ultrasound treatment nor removal of iron 


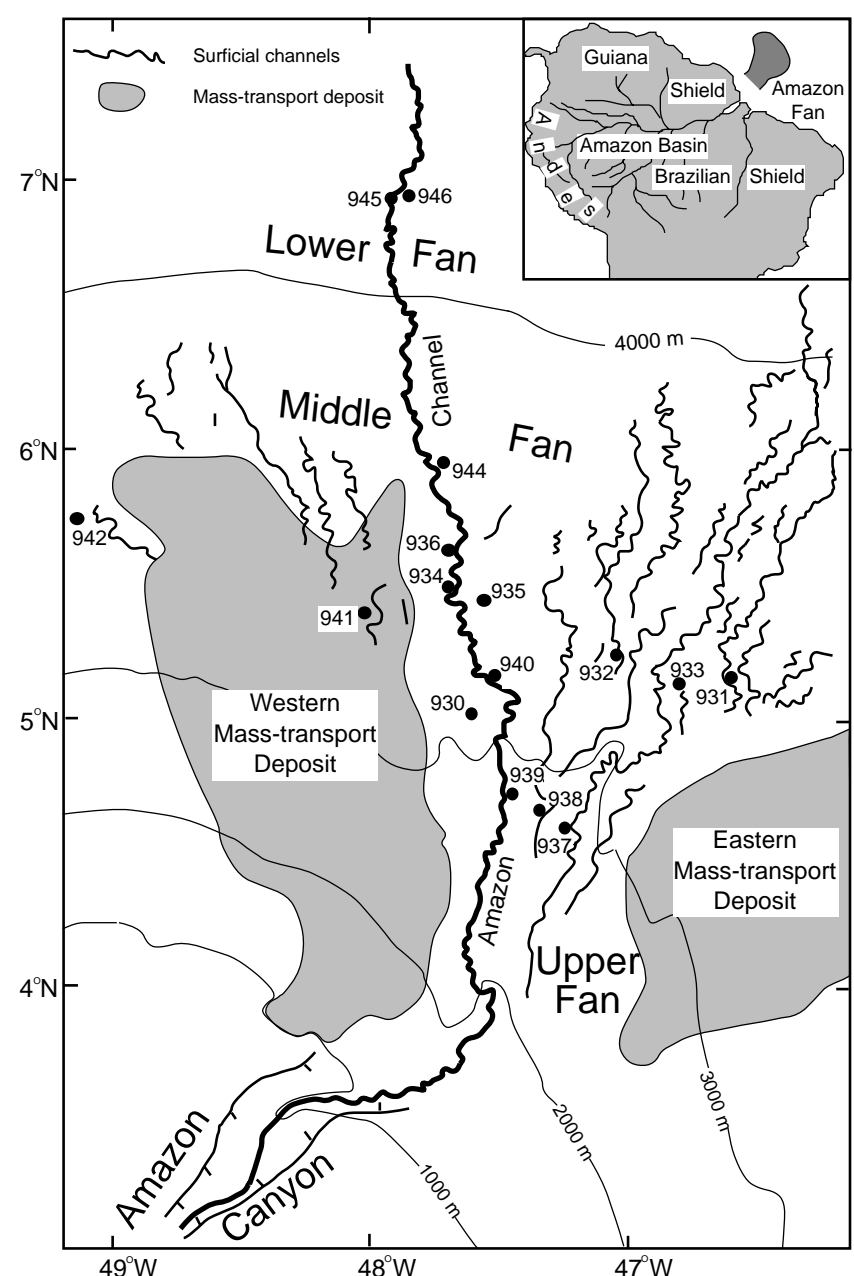

Figure 1. Map of Amazon Fan showing sites from which fine-grained turbidites have been studied. Map modified from Damuth et al. (1988) and Manley and Flood (1988).

oxide by sodium dithionite and sodium citrate had a significant effect on grain-size distribution (see data tabulated in Cramp et al., this volume). Samples were analyzed using $30-\mu \mathrm{m}$ and $200-\mu \mathrm{m}$ apertures, yielding estimates of frequency distribution for each $1 / 3 \phi$ range from $3.5 \phi$ to $11.8 \phi$. No attempt was made to determine the proportion of sediment finer than $11.8 \phi$; the samples analyzed contain no mineral grains coarser than $3.5 \phi$, although a few coarser foraminifers and wood fragments are present and were sieved through a $4 \phi$ sieve. Because it commonly is impossible to sample individual silt laminae without some mud contamination, and vice versa, modal size is more useful than mean size in interpreting grain-size variation. Most grainsize analyses are presented graphically as stacked frequency curves to facilitate comparison through individual beds.

Most samples studied were from cores recovered by the Advanced Piston Corer (APC) and appear not to have suffered significant deformation during coring. Samples from deeper in holes were recovered using the Extended Core Barrel (XCB) using very low pump rates to avoid washing away sediment. These cores experienced variable biscuiting, which may have affected the distribution of silt laminae (see fig. 7 of Shipboard Scientific Party, 1995a).

\section{EVIDENCE FOR THE TURBIDITE ORIGIN OF MUDDY SEQUENCES ON AMAZON FAN}

\section{Regional Sediment Distribution}

Evidence that the majority of mud beds on the Amazon Fan were deposited as turbidites includes the overall distribution of mud on the fan and the character of individual mud beds. We discuss these in turn.

The overall distribution of sediment shows that the thickness of the fine-grained component of the sediment column, for any seismically recognized stratigraphic interval, decreases away from the active fan channel. Change in thickness cannot be ascribed solely to decreases in the number of silt and sand beds. We illustrate this with an analysis of selected holes that penetrate the Amazon/Brown seismic interval (Fig. 3). Our data show that, after removing silt and sand beds, there is a five-tenfold decrease in mud sediment thickness from the levee crest to the open fan more than $10 \mathrm{~km}$ from the active channel. Taking the top of the Amazon interval as about $9 \mathrm{ka}$ and the base of the Brown as about $21 \mathrm{ka}$ (Piper et al., Chapter 39, this volume), this corresponds to an average annual sedimentation rate for mud of $10 \mathrm{~mm} / \mathrm{yr}$ on the levee crest at Sites 939, 940 and 944; $2 \mathrm{~mm} / \mathrm{yr}$ at Site $935,12 \mathrm{~km}$ from the channel; and $<1.5 \mathrm{~mm} / \mathrm{yr}$ at Site $930,10 \mathrm{~km}$ from the channel.

\section{Character of Individual Beds}

Although many core intervals consist of a seemingly random alteration of silt and mud laminae and beds, in places bioturbated, some core intervals show distinctive features that suggest turbidite deposition. Once these clear features are found, many other subtle examples may be recognized. Three principal criteria for turbidite deposition have been used:

\section{Graded Beds}

In a turbidite environment, sharp-based silt beds that grade up into mud are generally interpreted as a single depositional event, although the position of the top of the bed may not be clear. Likewise, muds with silt laminae that decrease upward in frequency, thickness, and grain size show an overall grading that is characteristic of turbidity current deposition (Piper, 1972; Piper and Stow, 1991). Many beds from throughout the fan show such features, visible both on the split core face (Fig. 4) and from grain-size analyses up through a bed (Figs. 5-7). Grain-size changes may be recognized in the size of the silt sediment mode (Fig. 5), in the abundance of silt and the prominence of a silt sediment mode (Fig. 7), or in a gradual shift in the modal sediment size without the presence of a prominent silt mode (Fig. 8).

\section{Diagenetic Fronts}

In cases where probable turbidites can be recognized on the basis of grading, the muds immediately below the silty base of a probable turbidite commonly had an unusually dark diffuse bed $0.5-1.5 \mathrm{~cm}$ thick about $0.5-1.5 \mathrm{~cm}$ below the overlying turbidite (Fig. 7). In some cases, this dark diffuse bed had a central light lamina. The pattern is the result of diagenetic iron sulfides: it disappears on oxidation, and there is no significant grain-size difference between the dark and light muds (analyses $a$ and $b$, Fig. 7). These features are interpreted as redox-controlled diagenetic features resulting from the re-establishment of a pore-water profile after rapid deposition of a turbidite. Similar features have been described from many fine-grained turbidites 


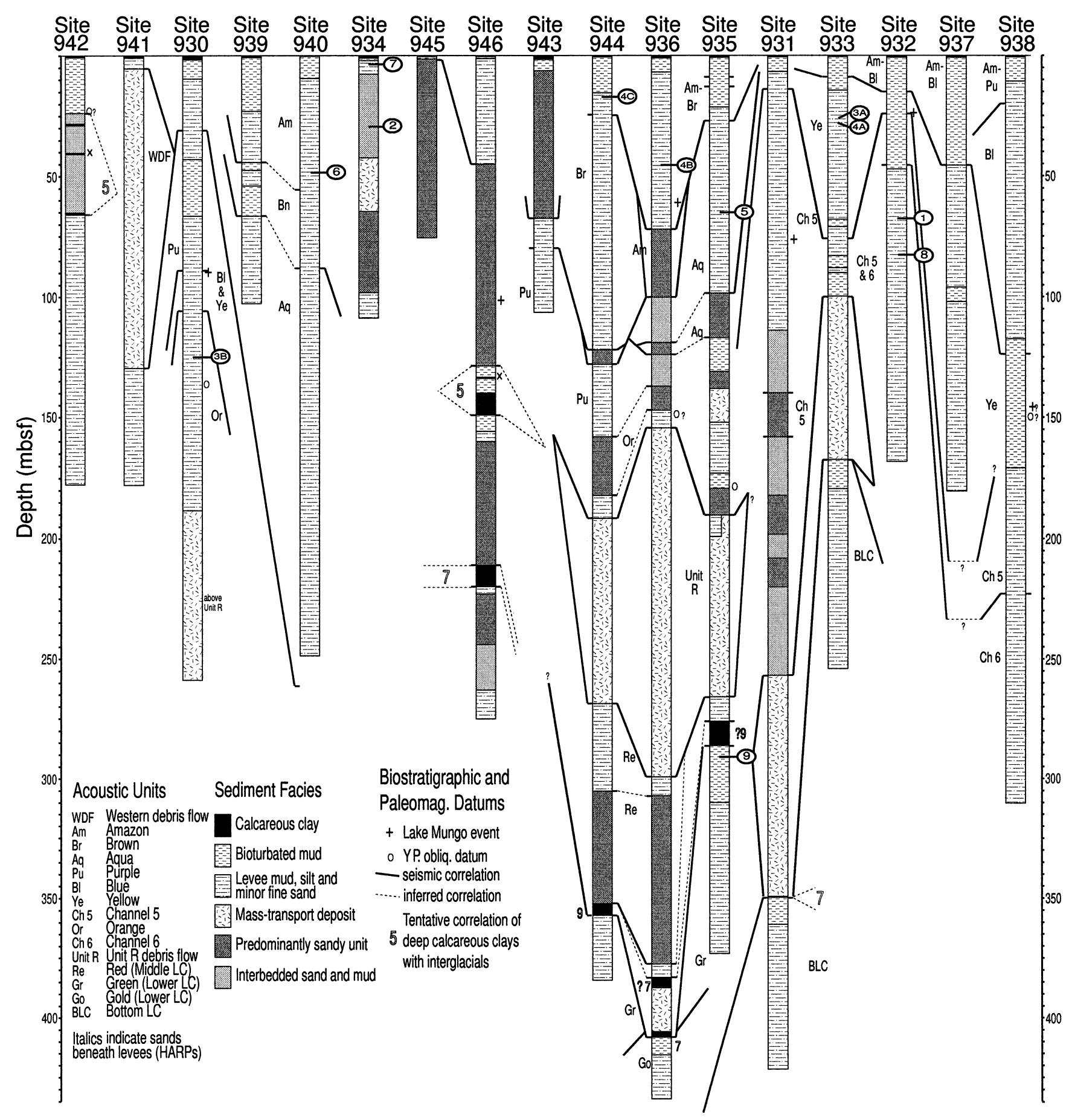

Figure 2. Simplified facies distribution in Amazon Fan sites showing location of type samples of each facies of fine-grained turbidite (cf. Table 1). Correlation from Shipboard Scientific Party (1995b). Location of all studied samples are presented in Figure 29.

and are best known from the Madeira Abyssal Plain (Jarvis and Higgs, 1987).

\section{Distribution of Calcareous Nannofossils}

Calcareous nannofossils are sparse to barren in most sections of levee mud from the Amazon Fan. Smear slides show that where there is an alternation of thin silts with muds, possibly representing turbidite beds several centimeters thick, then coccolith abundance is greatest in samples immediately below the base of major silts. Coccoliths are generally absent or extremely rare in smear slides from most muds, but three to seven individuals may be found in a smear slide from just below silts (Fig. 9). This observation suggests that the muds are derived from shallow water or deltaic environments and are re- 


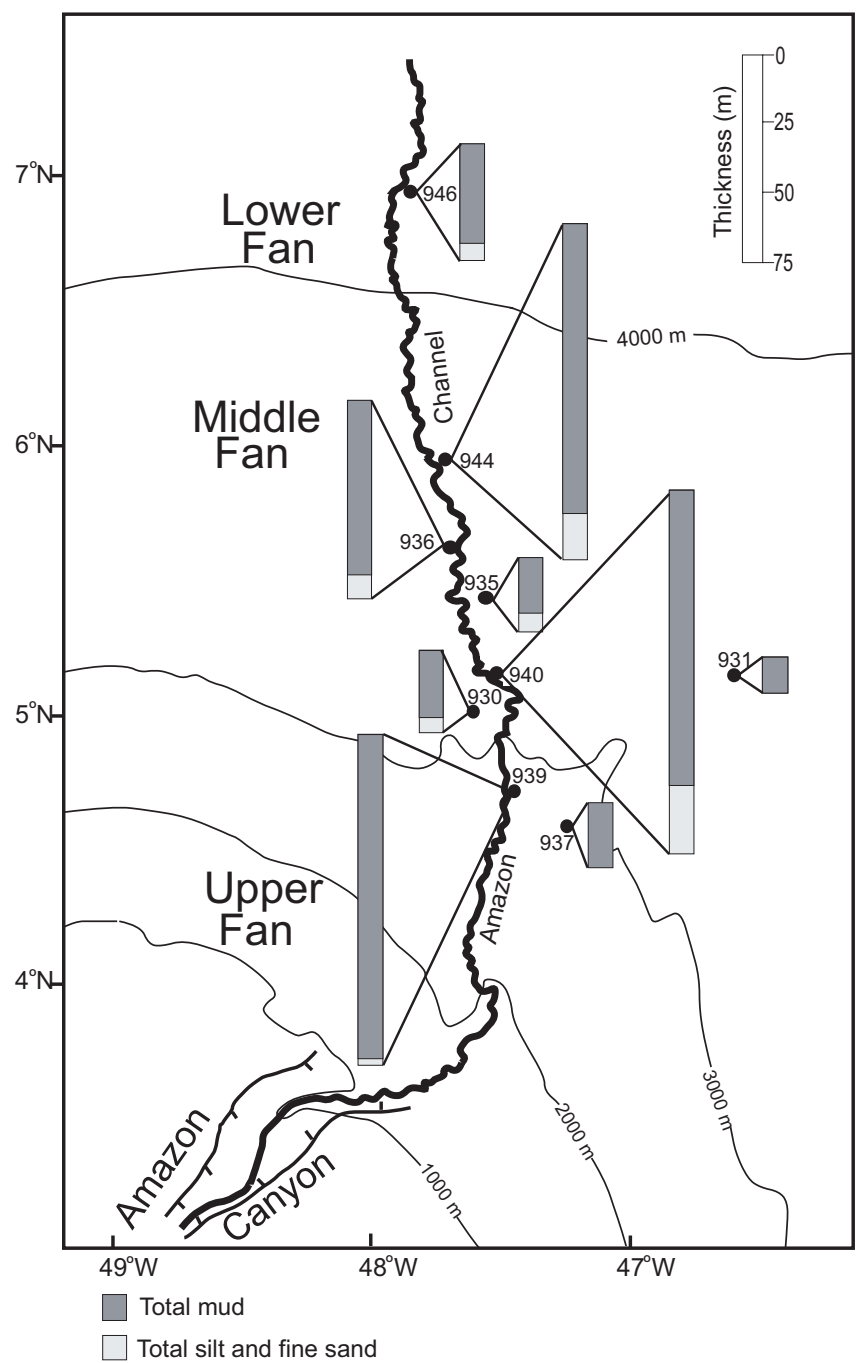

Figure 3. Thickness of mud compared with thickness of fine sand + silt in the Amazon/Brown interval ( 9-21 ka). Correlation of the base of the Amazon/ Brown is based on seismic-reflection profiles and oxygen isotope curves (see Showers et al., this volume).

sedimented rapidly, with a few pelagic coccoliths accumulating at the seabed prior to deposition of the next turbidite.

\section{Turbidite Bed Characteristics}

Using the three criteria outlined above allows additional indicators of turbidites to be identified. Although no indicator on its own is intrinsically diagnostic, together, they were used to identify depositional units in sections interpreted as turbidites. Using the three criteria, the following conclusions were drawn:

1. There was commonly a color gradation on the freshly split core face, with an upward decrease in darkness of sediment through the $a$-designated turbidite beds, interrupted only by diagenetic fronts (e.g., Figs. 7, 8). Many silt laminae, including laminae at the base of beds, were particularly dark prior to oxidation of the core surface (e.g., $c$ and $d$ in Fig. 7).

2. Mottling, interpreted as diagenetic alteration around bioturbation, is common in the upper part of the beds (e.g., $37-41 \mathrm{~cm}$ in Fig. 7), but does not affect laminated mud and silt lower in a bed.
3. In some sections, abrupt changes in the intensity of bioturbational mottling ( $84-89 \mathrm{~cm}$ in Fig. 10) suggest that some turbidite beds sat at the seabed for considerable time before another bed was deposited over them, whereas others were rapidly buried by a subsequent bed.

\section{DESCRIPTION OF FINE-GRAINED TURBIDITE FACIES}

We have developed a simple classification of fine-grained turbidite facies (Table 1) based on features that were clearly visible in the freshly split core face. For most facies, we present a type example with a core photograph, X-radiograph, core description, and an interval with detailed grain-size analysis. We then use this classification to examine variation of facies on the fan.

\section{Facies 1: Thin Graded, Sorted Silt to Mud Beds, No Silt Laminae}

Facies 1 consists of sorted silt beds, 4-20 mm thick, generally parallel laminated, some cross laminated, with a sharp base, and a sharp or gradational top to dark silty mud or mud. Some beds grade up to lighter colored mud and some show diagenetic fronts. In the type example (Fig. 11), the basal silt is about $3 \mathrm{~cm}$ thick. The overlying mud shows some color banding, but no discrete silt laminae are visible. In the $2-3 \mathrm{~cm}$ above the silt, the modal size of the mud decreases upward. The top of the depositional unit is picked at the base of the next silt bed, although it is possible that the mottled interval between 65 and $69 \mathrm{~cm}$ represents the top of the bed. In another example (Fig. 12), the silt beds are internally well laminated and show grading by a slight upward shift in the mode. A third example presented (Fig. 13) is more difficult to interpret. Silt beds and laminae, mostly a few millimeters thick, alternate with mud laminae of similar thickness. Some dark zones are developed in silt laminae, others may be diagenetic fronts.

\section{Facies 2: Thick Silty Mud Turbidites with Silt/Sand at the Base}

This uncommon facies consists of a basal silt or very fine sand bed many centimeters thick, commonly with a rather irregular distribution of sand, passing up into muddy silt and then to silty mud. Within the muddy silt and silty mud are discontinuous $2-3 \mathrm{~mm}$ laminae lower in the turbidite and similar sized blebs of silt higher up. In the type section (Fig. 14), the top of the bed is a lighter colored mud with a diagenetic front (that was oxidized away by the time the core photograph was taken). A rather similar facies was described by Piper (1973) from the Gulf of Alaska.

\section{Facies 3A: Sorted Sand/Silt Beds with Prominent $T_{d}$ Grading up into Mud}

Facies $3 \mathrm{~A}$ consists of graded very fine sand to silt beds passing up into alternating 1-2 mm laminae of silt and mud and then up into lighter mud (Fig. 5). The basal silt bed has a sharp base and is commonly parallel laminated or rarely cross laminated. The alternating silt and mud laminae correspond to the Bouma $T_{d}$ division and the $T_{2}$ to $T_{5}$ intervals of Stow and Shanmugam (1980). In some cases, the lighter mud at the top of the bed is bioturbated or has a diagenetic front. The grain-size analysis in the type section (Fig. 5) illustrates the overall size grading of this facies.

\section{Facies 3B: Sorted Silt Beds Grading Up into Mud Beds with 1-3 Silt Laminae}

Facies 3B is transitional between Facies 1 and Facies 3A. It typically consists of a sorted silt bed, 4-20 mm thick, that passes up through mud with one to three indistinct, poorly organized silty lam- 


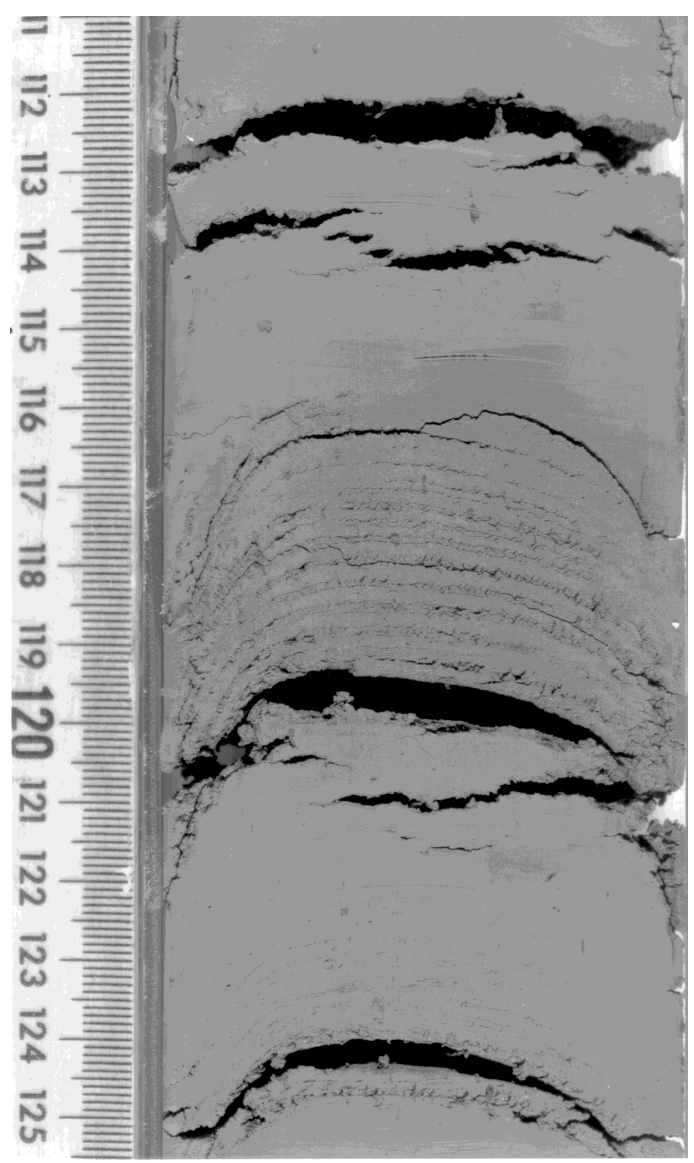

Figure 4. Photograph of alternating silt and mud laminae, with an upward decrease in the thickness of individual silt laminae. This is the type example of Facies $4 \mathrm{~A}$, well-defined $\mathrm{T}_{\mathrm{d}}$ silt/mud laminae grading up into mud (Section 155-931B-4H-6).

inae, into mud. The silt bed is sharp based, commonly parallel laminated, rarely cross laminated. In the type example (Fig. 15), the prominent lamination is within the silt bed, and the silty laminae in the mud are barely visible in the photograph. In this example, the silt bed is not graded, but there is an irregular upward decrease in grain size in the mud. The silty laminae in mud can be seen more clearly in Figure 8. Grain-size analysis in another example (Fig. 16) also shows no grading in the silt bed, followed by a gradual upward decrease in modal size in the mud.

\section{Facies 4A: Well-Defined $T_{d}$ Silt/Mud Laminae Grading up into Mud}

Facies 4A is essentially the same as Facies $3 \mathrm{~A}$ but lacks the basal silt bed. It thus corresponds to a $\mathrm{T}_{3}-\mathrm{T}_{7}$ sequence of Stow and Shanmugam (1980). It consists of alternating well-defined laminae of silt and mud (Fig. 4).

\section{Facies 4B: Poorly Defined $T_{d}$ Silt/Mud Laminae Grading up into Mud}

Facies 4B resembles Facies 3B, but it lacks the basal silt bed. It differs from Facies $4 \mathrm{~A}$ in that the alternating silt and mud laminae are less well defined and less clearly form a graded bed. The type section (Fig. 17) shows no grading up through the bed, except for the absence of silt in the mud at the top of the bed. The top of the bed is a little lighter in color and is bioturbated. Figure 18 shows an alternation of silt $(\mathrm{s})$ and mud $(\mathrm{m})$ laminae, with irregular upward variation in grain size in the silt laminae. (This example is transitional to Facies 4C, described below).

\section{Facies 4C: Very Fine $T_{d}$ Silt/Mud Laminae Grading up into Mud}

Facies $4 \mathrm{C}$ has rather poorly defined and very thin silt laminae in mud, but it shows good overall grading up into mud (Fig. 19). X-radiograph images show a fine lamination. Note that silt laminae are so thin that any grain-size analyses must sample both silt and mud laminae.

The core in Figure 20 illustrates a section with frequent silt laminae in which it is difficult to distinguish individual events. Aboard ship, three depositional events, based on color, were recognized with bases at $99.8,100.6$, and $101.8 \mathrm{~cm}$. The X-radiograph shows laminae, but it does not distinguish events. Detailed grain-size analysis shows that the bed with a base at $100.6 \mathrm{~cm}$ appears to be continuously graded up from the underlying bed with its base at $101.8 \mathrm{~cm}$. The abrupt increase in grain size at $99.8 \mathrm{~cm}$ is confirmed.

\section{Facies 5: Beds with Starved Silt Ripples and Thick Lenticular Silt Laminae}

Facies 5 consists of lenticular silt laminae, 4-10 mm thick, some of which show fading ripples (cf. Stow et al., 1984). Commonly the thick lenticular lamina passes up into mud through one or two discontinuous <1-mm laminae of silt (Fig. 21). Individual turbidite beds appear to be a few centimeters thick. In XCB cores, some apparent occurrences of this facies may be an artifact of biscuiting.

\section{Facies 6: Beds with Groups of Thin Lenticular Silt Laminae}

Facies 6 is similar to Facies 5, but has thinner silt laminae (Fig. 22) typically $0.5-2 \mathrm{~mm}$ thick. Many of the laminae are discontinuous, and there is commonly no clear system to the distribution of laminae, although some pass up into a dark mud bed with a definable top. In the type example (Fig. 22), this facies is associated with sand beds with irregular erosive bases.

\section{Facies 7: Mud Turbidites with Basal Silt Lamina}

Facies 7 consists of dark mud apparently grading up from a single sorted silt lamina, 1-2 mm thick, at the base (Fig. 7). In many cases, there is color banding in the mud in the lower part of the bed, and the muds grade upward to a lighter color. In the type example, the recognition of a 15-cm-thick bed representing a single turbidite is based on grain-size grading, the presence of diagenetic fronts, and the distribution of coccoliths.

Figure 23 shows another thick mud bed of Facies 7 with a gradual upward decrease in modal grain size. The core face shows pronounced black lamination in the mud, seen less clearly in the X-radiograph. The continuity of lamination in the X-radiograph suggests that in this case the mottling may not be related to bioturbation. The basal silt lamina was not analyzed for grain size.

\section{Facies 8: Mud Turbidites with Poorly Sorted Muddy Silt at the Base}

Facies 8 is similar to Facies 7, but instead of a sorted silt lamina at the base, the mud grades up from a poorly sorted muddy silt (Fig. 10).

\section{Facies 9: Mud Turbidites Lacking Basal Silt Lamina}

Facies 9 is similar to Facies 7 and 8, but it lacks any basal silt or muddy silt laminae (Fig. 24). The mud shows an upward grading in 


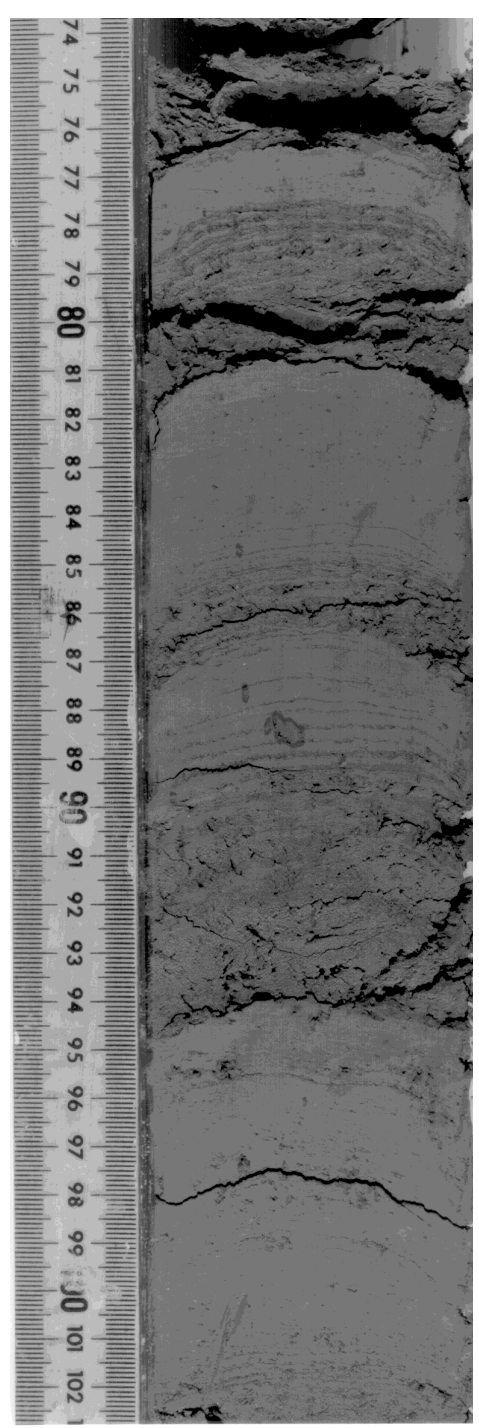

Core photograph

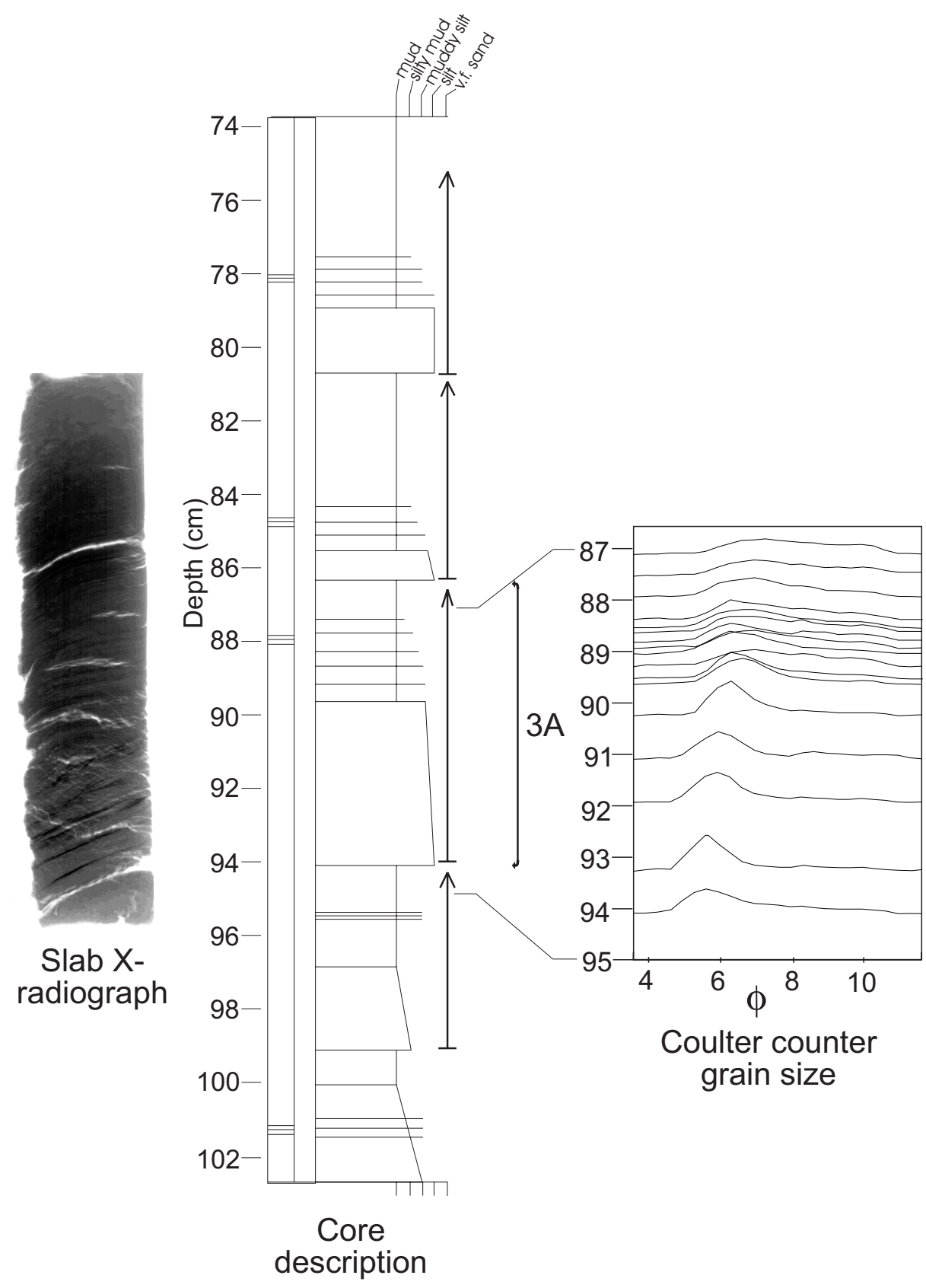

Figure 5. Graded silt bed passing up into mud with silt laminae and then mud. Upward decrease in grain size is clearly visible in the shift of modal grain size. This is the type example of Facies 3A, sorted sand/silt beds with prominent $\mathrm{T}_{\mathrm{d}}$ grading up into mud (Section 155-931A-4H-2). For legend, see Fig. 6.

modal size and commonly becomes lighter upward. The top part of the bed may be bioturbated. Rarely, a few indistinct silty laminae are found within the bed.

A detailed grain-size profile through a mud turbidite of Facies 9 is shown in Figure 23. The bed is recognized from its distinctive color, and it overlies a diagenetic front doublet. The base of the bed has a distinctly coarser mode than the underlying mud, and the bed shows an overall upward decrease in modal mud size, although some reverse fluctuations are present.

The example of this facies shown in Figure 25 may be disturbed by biscuiting. It consists of a weakly graded mud bed about $6 \mathrm{~cm}$ thick. This facies of mud turbidites is very common at Site 939 (Fig. 26).

\section{DISTRIBUTION AND INTERPRETATION OF FINE- GRAINED TURBIDITE FACIES}

\section{Variations in Grain Size}

Modal silt size of fine-grained turbidites may show some systematic variation downfan. Most analyzed samples come from mud intervals that are interbedded on a decameter scale with coarse silt to very fine sand beds. In this sense, there is a wide range of silt grain sizes at all sites.

We used the Coulter counter grain-size determinations to estimate downfan variation in grain size (Fig. 27). For each site, the modal sizes of silt intervals and mud intervals were compiled, and the mode of 


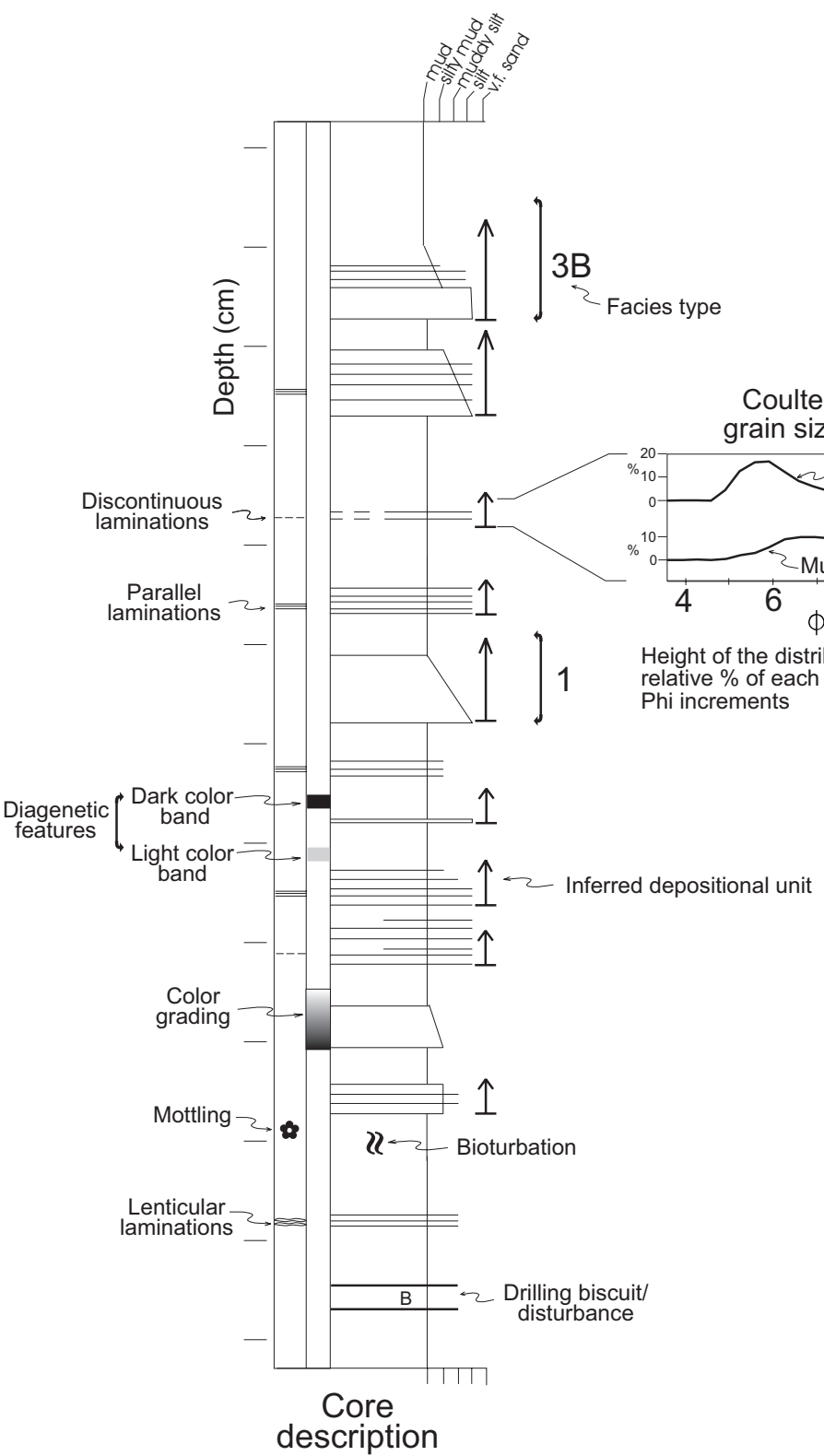

these modal determinations at every site was then determined. The samples that were analyzed do not represent a random sample of the sediments on the fan; they tend to be biased toward muddy unbioturbated intervals with only thin silt laminae. Nevertheless, some general trends emerge from the data. Modal silt size decreases from $5.6 \phi$ on the upper fan to $6.3 \phi$ on the lower fan. Modal mud size decreases from $6.3 \phi$ on the upper fan to $7.3 \phi$ on the lower fan. These trends are similar to those reported by Piper (1978), who found that on several fans the mean grain size of both mud and silt intervals decreased downfan.

\section{Distribution in Relation to Channels}

Facies distribution of fine-grained turbidites in relation to channels cannot be examined in isolation from variation in overall facies. A transect from upper fan to lower fan along the Amazon Channel (see Plate 1, Flood, Piper, Klaus, et al. 1995) shows abundant muds at the shallowest water Site 939 (Fig. 3). Offset holes at Site 939 show that a 100-m-thick section $1 \mathrm{~km}$ from the levee crest thins to 93 $\mathrm{m}$ at $1.5 \mathrm{~km}$ from the levee crest. Both the number and thickness of silt beds decreases away from the levee crest, and mud beds appear
Figure 6. Legend for standard core plots. The figure also shows a grain-size frequency plot for a typical silt lamina and a typical mud. to show a similar pattern. At Site 940, there is a much higher proportion of silt beds and laminae, although some intervals of the levee are predominantly mud in places that are bioturbated. Site 944 , on the mid fan, has a similar abundance of silt beds and laminae. Hole 944B, $300 \mathrm{~m}$ from the levee crest, has silt beds $1-5 \mathrm{~cm}$ thick that appear to be equivalent to 5- to 10-mm silt laminae at Holes 944A and 944D, respectively $600 \mathrm{~m}$ and $900 \mathrm{~m}$ from the levee crest. Site 946 is located on the levee near the termination of the Amazon Channel. Because of distributary switching, levee sediments have not accumulated for as long at this site as at sites further upfan. Silt beds are abundant, but the overall silt-to-mud ratio is less than at Sites 940 and 944 (Fig. 3).

Some facies seem to characterize environments close to channels. In particular, the rather disorganized sediment of Facies 2 is found only at Site 934. This site is situated in an abandoned meander bend $55 \mathrm{~m}$ above the present channel floor. Facies 2 was deposited after abandonment of the meander and is thus analogous to deposition on an unusually low levee. It probably represents deposition from a rapidly decelerating thick current carrying large amounts of silt.

Facies 1 and 2, through $3 \mathrm{~B}$ and $4 \mathrm{~B}$ to $3 \mathrm{~A}$ and $4 \mathrm{~A}$, show a gradual transition from a fairly continuous passage from silt up to mud to a transition in which there is a prominent alternation of silt and mud. 


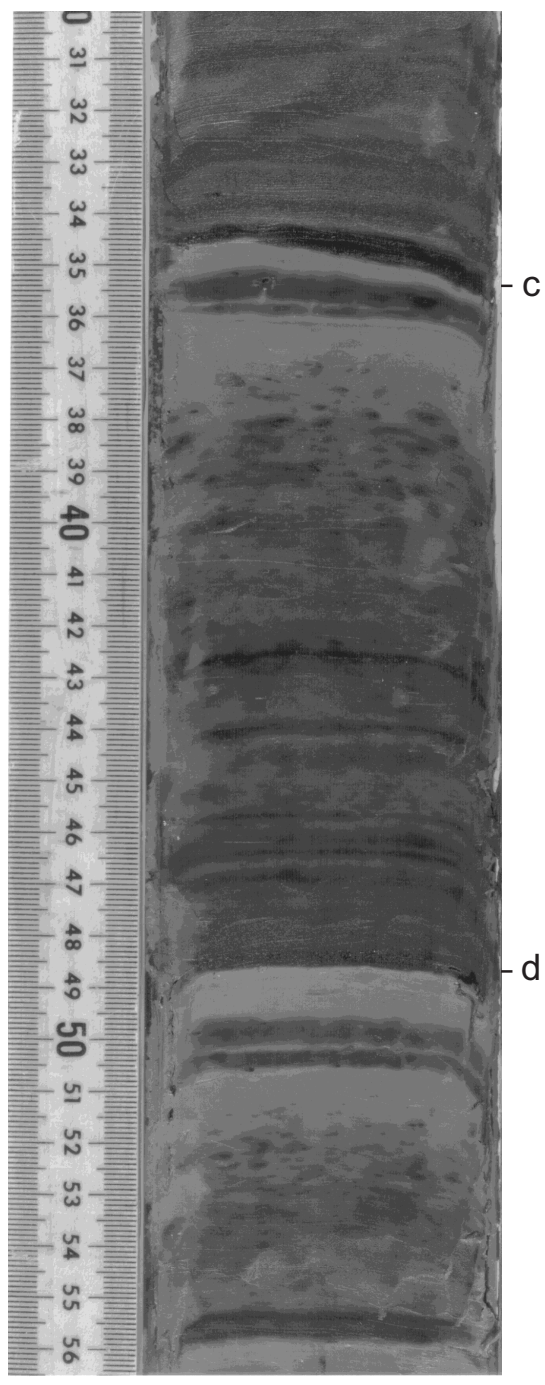

Core photograph
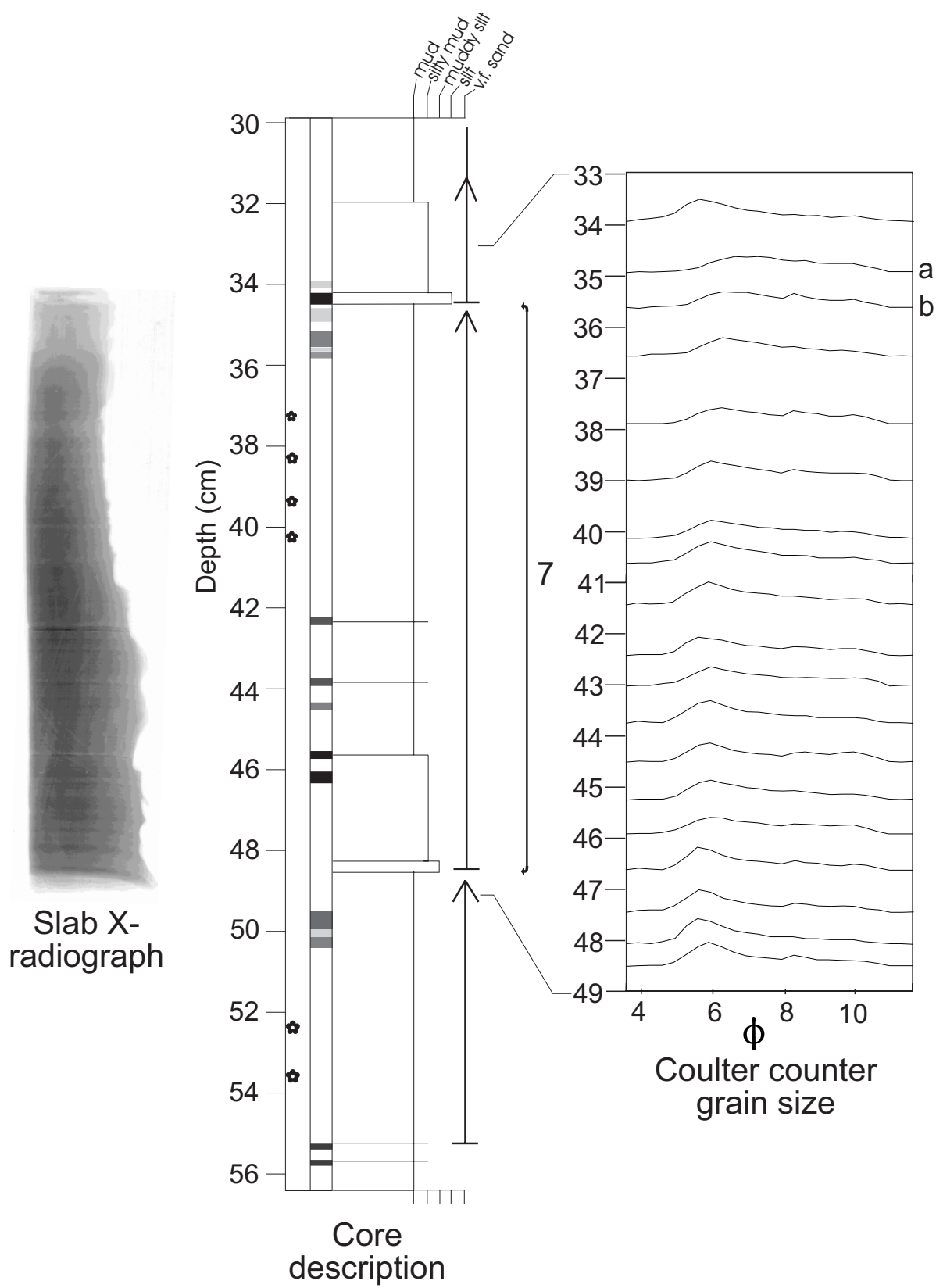

Figure 7. Graded mud beds with an upward decrease in the abundance of silt and a diffuse dark doublet near the top of each inferred turbidite. This is the type example of Facies 7, mud turbidites with a basal silt lamina (Section 155-934A-1H-3). $a=$ dark mud; $b=$ adjacent light mud; $\mathrm{c}$ and $\mathrm{d}=\mathrm{dark}$ silt laminae discussed in text.

Where there is the alternating transition in Facies 3A, the underlying silt bed is graded in contrast to Facies $3 \mathrm{~B}$ in which grading is not recognized in the basal silt. Although Facies 1 occurs in many of the same intervals as Facies 3 and 4, it is particularly common near levee crests in upfan Sites 939 and 940 and less common on levee flanks and downfan sites. At Site 944, Facies 3A, 4A, and 4C are common in Hole D, furthest down the flank, whereas Facies $3 B$ and $4 B$ are more common in Hole A nearer the crest. This distribution suggests that as a turbidity current evolves through time, conditions for deposition of a prominent $T_{d}$ interval are more favored.

Overall, we propose the following sequence from levees on the upper fan through to the lower fan (Figs. 28, 29; Table 2 on CDROM, back pocket, this volume):
1. Mud turbidites (Facies 8 and 9) are abundant on the upper fan. Their frequency is consistent with the overall dominance of mud in these sequences. Where there is a basal silt, it is not well sorted. Silt beds are most commonly Facies 1, lacking good $\mathrm{T}_{\mathrm{d}}$ division.

2. Muds with starved silt laminae (Facies 5 and 6) are most common on levees of the mid fan. Although the sample size is small, Facies 5 appears most common during the Brown seismic interval, at the peak of the last glacial maximum when the sea level was lowest.

3. Prominent $T_{d}$ division silt laminae are most common on the middle fan. The less organized Facies $3 \mathrm{~B}$ and $4 \mathrm{~B}$ are more common near levee crests and upfan, whereas the more orga- 

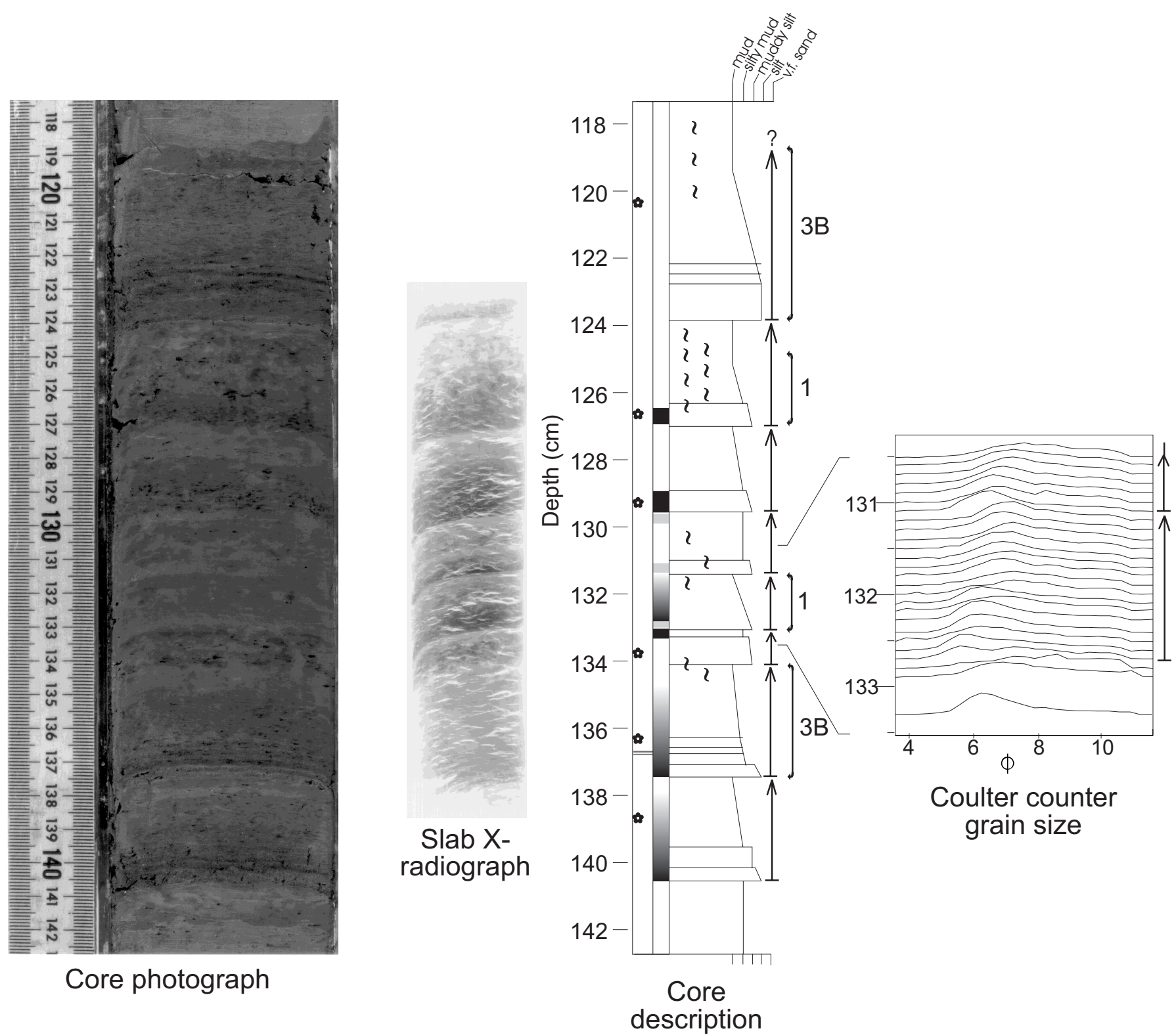

Figure 8. Gradual upward decrease in the modal grain size in turbidite mud, visible in both Coulter counter grain-size analyses and in X-radiograph. Note also color grading to lighter color up through a bed. Facies 3B, sorted silt bed grading into mud with rare silty laminae (Section 155-946A-2H-3).

nized $3 \mathrm{~A}$ and $4 \mathrm{~A}$ are more common on levee flanks and downfan.

4. Fine-grained silts of Facies $4 \mathrm{C}$ are most common on flanks of levees on the lower part of the mid fan.

5. Poorly sorted silt beds of Facies 2 and Facies 7 are most common at Site 934, where turbidity currents spilled into a meander cut-off, rather than across a full-height levee. Mud turbidite beds at this site are thicker than at most other sites.

We suggest a general process explanation for these changes. Passing downfan, the general channel gradient, the talweg gradient, and the levee gradient all decrease, although the levee gradient is greater than both the talweg and channel gradients (Pirmez and Flood, 1995). At the same time, channel depth decreases downfan. Changes in facies down fan can be explained by (a) down fan increase in sorting and "organization" within the turbidity currents, (b) variations in the type of sediment spilling out of turbidity currents, and (c) levee gradients.

The muddy sediments on levees on the upper fan result from spillover of only the tops of turbidity currents, and silt that spills out is not well sorted. Starved and lenticular silts on the mid fan result from spillover principally of mud, with minor coarse silt, and acceleration of flows down levee flanks occurs as a result of the gradient increase. The $T_{d}$ silt laminae represent some behavior of the flow that is well developed on the lower mid fan but does not occur at spillover of levees on the upper fan. The increase in silt laminae in fine-grained overbank deposits passing downstream suggests that, within an internally graded turbidity current, only the topmost muddy part spills out on the upper fan, but deeper parts of the flow, carrying silt in suspension, are able to spill out on the lower fan.

Stanley (1981) proposed that thick mud beds showing little grading or no grading are the result of prolonged deposition by low con- 


\section{Core $934 \mathrm{~A}-1 \mathrm{H}-2$}

Figure 9. Examples of the distribution of coccoliths in selected beds. $\mathrm{r}=$ rare; $\mathrm{vr}=$ very rare; $\mathrm{t}=$ trace as defined in the "Explanatory Notes" chapter, p. 58 (Shipboard Scientific Party, 1995a). Numbers indicate total numbers of nannofossils per smear slide for samples in which abundances are only trace or absent.

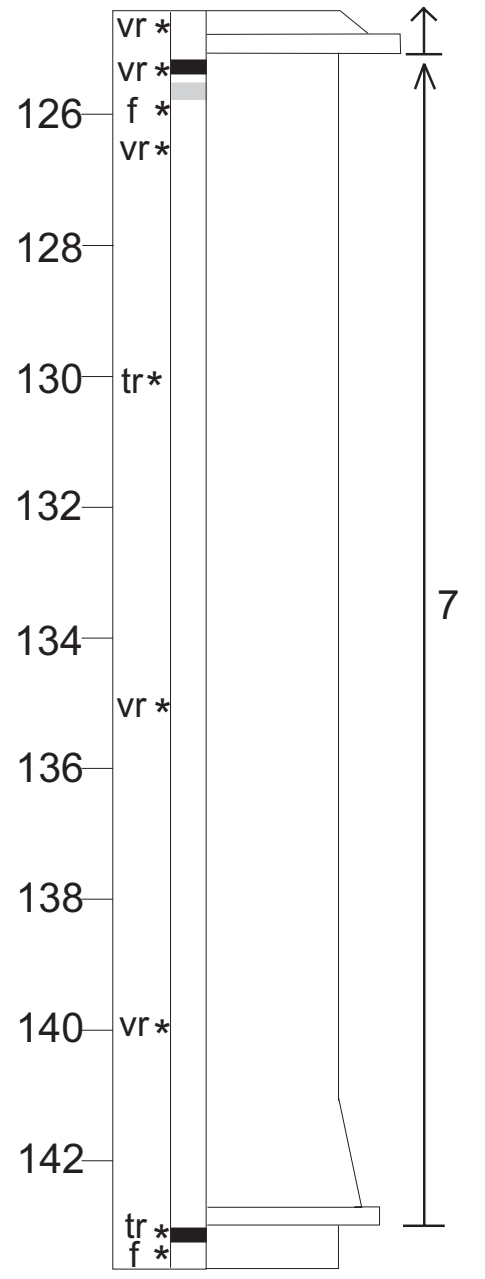

Core $946 \mathrm{~A}-7 \mathrm{H}-4$

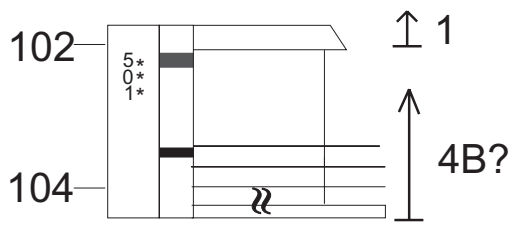

Core $946 \mathrm{~A}-2 \mathrm{H}-3$

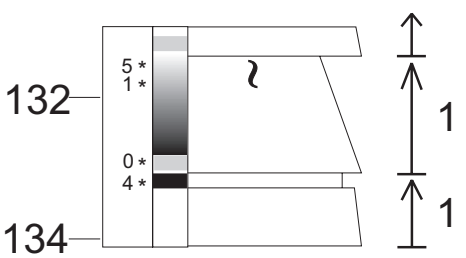

centration flows and has termed such beds "unifites." Many of the Facies 9 deposits resemble Stanley's unifites, in lacking structure or prominent grading. This facies is abundant at Site 939, where seafloor gradient is steep and overall mud thickness decreases rapidly away from the levee crest. This suggests that the facies is related to levee overspill processes and not to prolonged deposition.

\section{Variations in Bed Thickness and Frequency of Turbidite Deposition}

Mean turbidite mud bed thickness can be determined for several sites on the basis of shipboard millimeter-by-millimeter descriptions. Typically only two to four $30-\mathrm{cm}$ lengths of core were described from each Amazon levee site, so the sample is not very large and may be biased toward those intervals in which depositional units could be clearly recognized (i.e., perhaps where depositional units were thicker). Nevertheless, there is considerable consistency in estimates of frequency of depositional events averaged over the entire Amazon/ Brown seismic interval for Sites 939 (limited data, 0.2/yr), 936 (0.15/ yr), $944(0.18 / y r)$, and $946(>0.3 / y r)$. These data suggest a probable increase in frequency of overbank deposits passing downfan and the mean frequency of overbank deposition is one turbidity current every 3-8 yr between 9 and $21 \mathrm{ka}$. These estimates are comparable with frequencies estimated from cable breaks seaward of two modern muddy-discharge rivers, the Zaire (Congo) and the Magdalena (Heezen and Hollister, 1971).

Thus, both the proportion of overbank silt increases downfan and the number of overbank events probably increases. The increase in overbank silt implies that deeper levels in turbidity current are overtopping the levees, and the increase in frequency downfan suggests that some currents that are totally confined to the channel on the upper fan can spill out on the lower fan. The frequency of turbidity currents passing through the channel thus probably exceeds 1 every $3 \mathrm{yr}$. This estimate is probably low (i.e., the frequency is higher) because of the difficulty of recognizing very thin turbidites.

\section{CONCLUSIONS}

1. Much of the fine-grained sediment on Amazon Fan levees consists of mud with silt laminae.

2. The distribution of sharp-based graded beds and the distribution of bioturbation, diagenetic fronts, and nannofossils demonstrates the turbidite origin of many of the beds.

3. Twelve facies types are distinguished and their sedimentary structures and grain size are characterized.

4. Mud turbidites and Facies 1 silt-mud beds are most common on the upper fan. Muds with starved silt laminae (Facies 5 and 6) are restricted to levees on the mid fan, particularly at the last glacial maximum. Prominent $T_{d}$ division silt laminae are most common on the middle fan, with less-organized facies most abundant near levee crests. Fine-grained silts of Facies 4C are most common on flanks of levees on the lower part of the mid fan. Thick beds of mud with poorly sorted silt of Facies 2 and 7 are largely restricted to Site 934 , where turbidity currents 

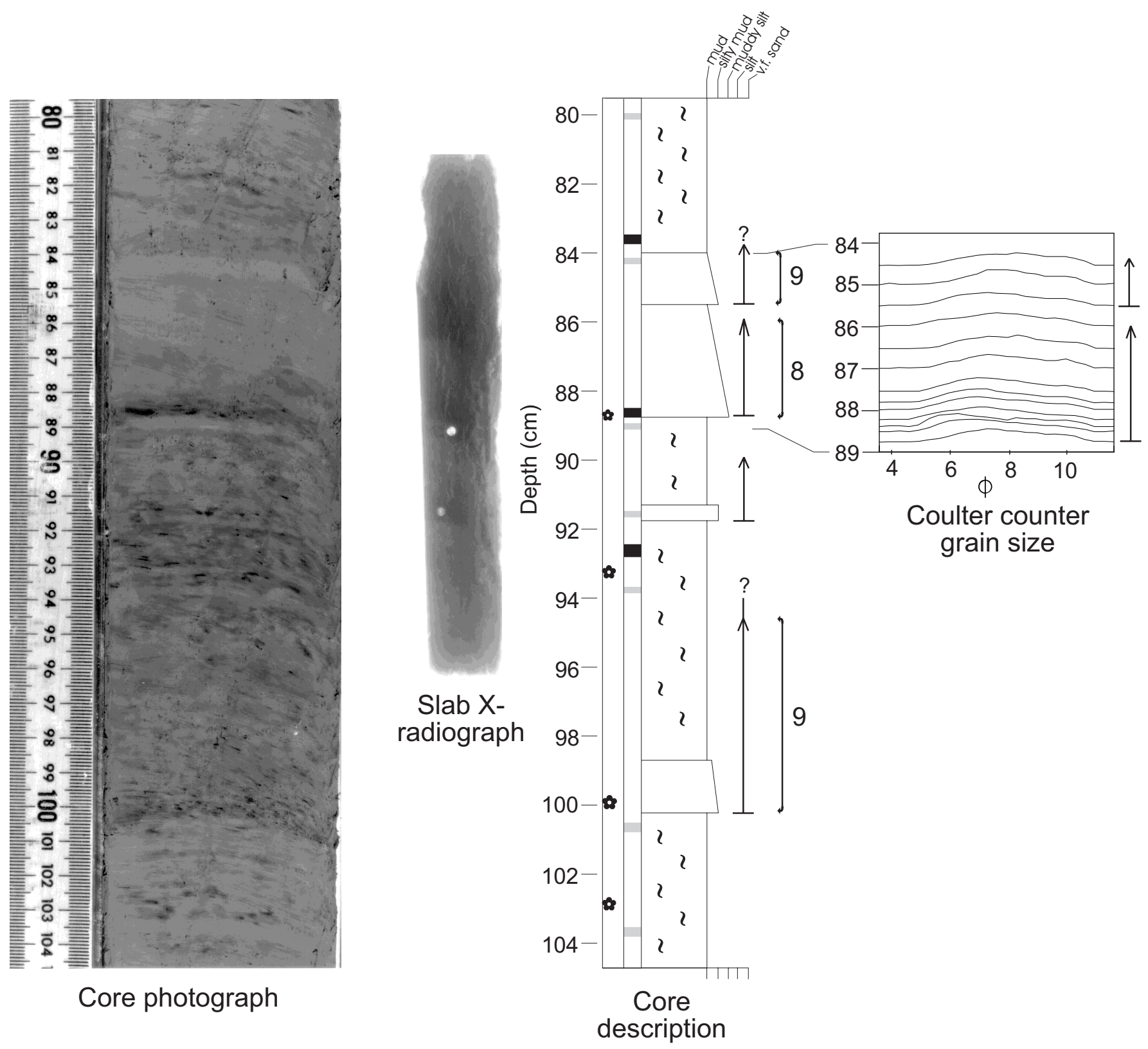

Figure 10. Abrupt changes in the intensity of bioturbational mottling in mud beds. Note that within the mud bed, there is a gradual upward decrease in the modal sediment size (Section 155-932A-10H-1). This is the type section of fine-grained turbidite Facies 8, mud turbidite with poorly sorted muddy silt at the base.

Table 1. Classification of fine-grained turbidites from the Amazon Fan.

\begin{tabular}{|c|c|c|c|}
\hline Facies & $\begin{array}{l}\text { Type } \\
\text { section }\end{array}$ & Other examples & Brief description \\
\hline $1 \mathrm{~A}$ & Fig. 11 & Figs. 12, 13 & Thin graded, sorted silt to mud bed, no silt laminae. \\
\hline 2 & Fig. 14 & & Thick silty mud turbidite with blebs of sand at base. \\
\hline $3 \mathrm{~A}$ & Fig. 5 & & Sorted sand/silt bed with prominent $\mathrm{T}_{\mathrm{d}}$ grading up into mud. \\
\hline 3B & Fig. 15 & Figs. 8,16 & Sorted silt bed grading into mud with rare silty laminae. \\
\hline $4 \mathrm{~A}$ & Fig. 4 & & Well-defined $\mathrm{T}_{\mathrm{d}}$ silt/mud laminae grading up into mud. \\
\hline $4 \mathrm{~B}$ & Fig. 17 & Figs. 12,18 & Poorly defined $\mathrm{T}_{\mathrm{d}}$ silt $/ \mathrm{mud}$ laminae grading up into mud. \\
\hline $4 \mathrm{C}$ & Fig. 19 & Fig. 20 & Very fine $T_{d}$ silt/mud laminae grading up into mud. \\
\hline 5 & Fig. 21 & & Mud bed with starved silt ripples and thick lenticular silt laminae. \\
\hline 6 & Fig. 22 & & Mud bed with groups of thin lenticular silt laminae. \\
\hline 7 & Fig. 7 & Fig. 23 & Mud turbidite with basal silt lamina. \\
\hline 8 & Fig. 10 & & Mud turbidite with poorly sorted muddy silt at the base. \\
\hline 9 & Fig. 24 & Figs. $23,10,11,25,26$ & Mud turbidite lacking basal silt lamina. \\
\hline
\end{tabular}

Note: All figure references are to this paper. 

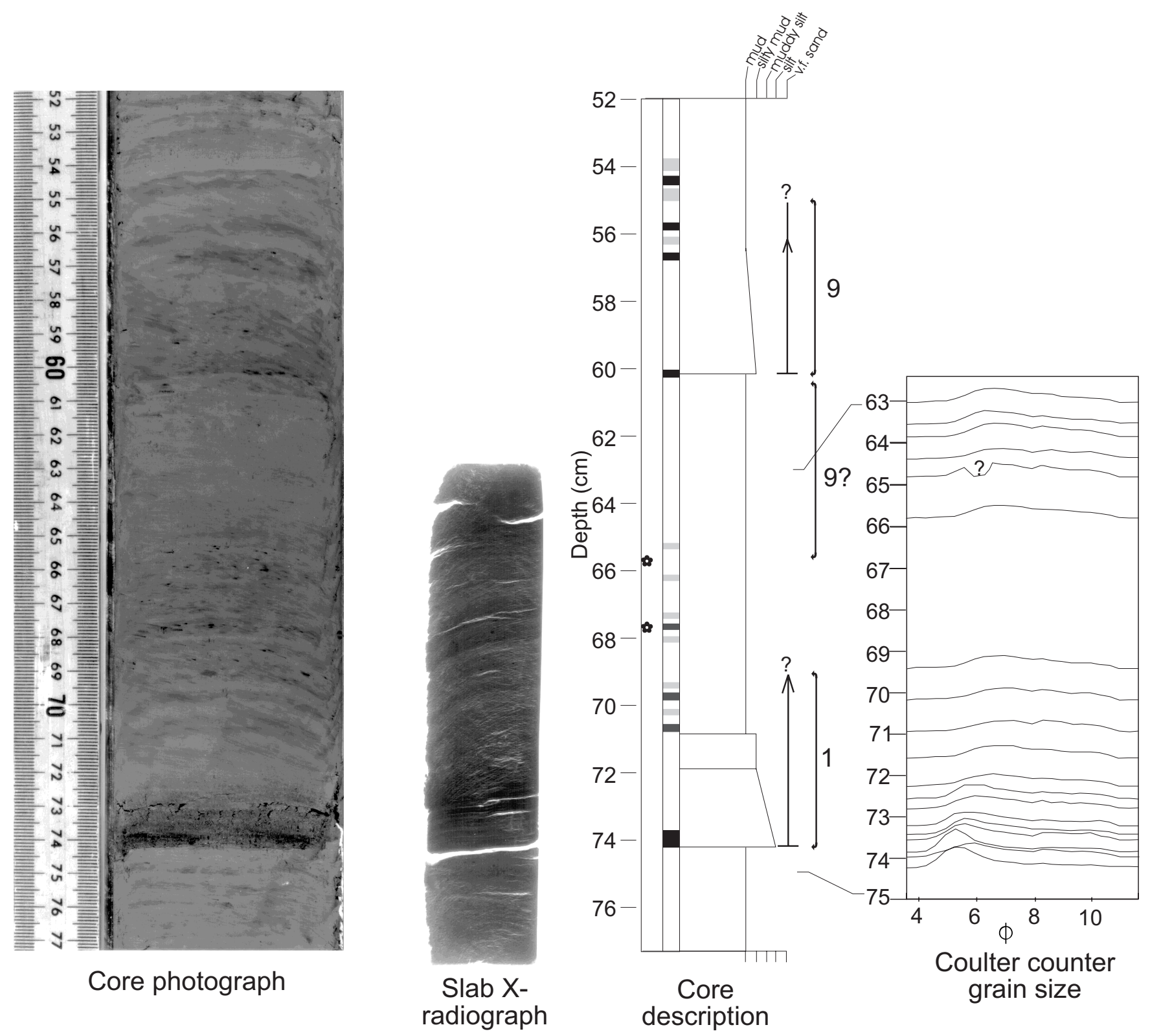

Figure 11. Type example of Facies 1 fine-grained turbidite, thin graded sorted silt to mud bed, no silt laminae (Section 155-932A-8H-7). This section also shows examples of Facies 9.

spilled into a meander cutoff, rather than across a full-height levee.

5. Modal grain size of both silt laminae and turbidite mud decreases downfan.

6. Turbidity currents spilled over levees with a frequency of 0.15 to $0.3 / y r$ during the last glacial maximum, with more turbidity currents spilling out downfan.

7. Facies distribution is consistent with progressive spillover of a greater thickness of turbidity currents as they move down the channel system.

\section{ACKNOWLEDGMENTS}

DJWP thanks the shipboard sedimentologists for their tolerance and help, and in particular Rick Hiscott for pointing out important features. Stan Johnson and Bill LeBlanc assisted with the Coulter counter analysis. MD was partly supported by a Canada ODP summer scholarship through the Natural Sciences and Engineering Research Council. Work supported by the Geological Survey of Canada. Reviews by Dorrik Stow and Michael Underwood improved the manuscript.

\section{REFERENCES}

Bouma, A.H., 1962. Sedimentology of Some Flysch Deposits: A Graphic Approach to Facies Interpretation: Amsterdam (Elsevier).

Carey, D.L., and Roy, D.C., 1985. Deposition of laminated shale: a field and experimental study. Geo-Mar. Lett., 5:3-9.

Damuth, J.E., Flood, R.D., Knowsmann, R.O., Belderson, R.H., Gorini, M.A., 1988. Anatomy and growth patterns of Amazon deep-sea fan as revealed by long-range side-scan sonar (GLORIA) and high-resolution seismic studies. AAPG Bull., 72:885:911.

Flood, R.D., Manley, P.L., Kowsmann, R.O., Appi, C.J., and Pirmez, C., 1991. Seismic facies and late Quaternary growth of Amazon submarine 
fan. In Weimer, P., and Link, M.H. (Eds.), Seismic Facies and Sedimentary Processes of Submarine Fans and Turbidite Systems: New York (Springer), 415-433.

Flood, R.D., Piper, D.J.W., Klaus, A., et al., 1995. Proc. ODP, Init. Repts., 155: College Station, TX (Ocean Drilling Program).

Flood, R.D., Piper, D.J.W., and Shipboard Scientific Party, 1995. Introduction. In Flood, R.D., Piper, D.J.W., Klaus, A., et al., Proc. ODP, Init. Repts., 155: College Station, TX (Ocean Drilling Program), 5-16.

Heezen, B.C., and Hollister, C.D., 1971. The Face of the Deep: New York (Oxford University Press).

Hesse, R., and Chough, S.K., 1980. Deposition of parallel-laminated levee muds from the viscous sublayer of low density turbidity currents. Sedimentology, 27:697-711

Jarvis, I., and Higgs, N., 1987. Trace-element mobility during early diagenesis in distal turbidites: late Quaternary of the Madeira Abyssal Plain, $\mathrm{N}$ Atlantic. In Weaver, P.P.E., and Thomson J. (Eds.), Geology and Geochemistry of Abyssal Plains. Geol. Soc. Spec. Publ. London, 31:179214.

Kranck, K., Smith, P.C., and Milligan, T.G., 1996. Grain size characteristics of fine-grained unflocculated sediments. I: "one-round" distributions. Sedimentology, 43:589-596.

Manley, P.L., and Flood, R.D., 1988. Cyclic sediment deposition within the Amazon deep-sea fan. AAPG Bull., 72:912-925.

McCave, I.N., and Jones, K.P.N., 1988. Deposition of ungraded muds from high-density non-turbulent turbidity currents. Nature, 333:250-252.

Piper, D.J.W., 1972. Turbidite origin of some laminated mudstones. Geol. Mag., 109:115-126.

1973. The sedimentology of silt turbidites from the Gulf of Alaska. In Kulm, L.D., and von Huene, R. (Eds), Init. Repts. DSDP, 18: Washington (U.S. Govt. Printing Office), 847-868.

, 1978. Turbidite muds and silts on deep-sea fans and abyssal plains. In Stanley, D.J., and Kelling, G. (Eds.), Sedimentation in Submarine Canyons, Fans and Trenches: Stroudsburg, PA (Hutchinson and Ross), 163-176.
Piper, D.J.W., and Stow, D.A.V., 1991. Fine-grained turbidites. In Einsele, G., and Seilacher, A. (Eds.), Cyclic and Event Stratification: New York (Springer Verlag), 360-376.

Pirmez, C., and Flood, R.D., 1995. Morphology and structure of Amazon Channel. In Flood, R.D., Piper, D.J.W., Klaus, A., et al., Proc. ODP, Init. Repts., 155: College Station, TX (Ocean Drilling Program), 23-45.

Shipboard Scientific Party, 1995a. Explanatory notes. In Flood, R.D., Piper, D.J.W., Klaus, A., et al., Proc. ODP, Init. Repts., 155: College Station, TX (Ocean Drilling Program), 47-81

1995b. Leg synthesis. In Flood, R.D., Piper, D.J.W., Klaus, A., et al., Proc. ODP, Init. Repts., 155: College Station, TX (Ocean Drilling Program), 17-21.

Stanley, D.J., 1981. Unifites: structureless muds of gravity-flow origin in Mediterranean basis. Geo-Mar. Lett., 1:77-84.

Stow, D.A.V., Alam, M., and Piper, D.J.W., 1984. Sedimentology of the Halifax Formation, Nova Scotia: Lower Paleozoic fine-grained turbidites. In Stow, D.A.V., and Piper, D.J.W. (Eds.), Fine-grained Sediments: Deepwater Processes and Facies. Geol. Soc. Spec. Publ. London, 15:127-144.

Stow, D.A.V., and Bowen, A.J., 1980. A physical model for the transport and sorting of fine-grained sediments by turbidity currents. Sedimentology, 27:31-46

Stow, D.A.V., and Shanmugam, G., 1980. Sequences of structures in finegrained turbidites: comparison of recent deep-sea and ancient flysch sediments. Sediment. Geol., 25:23-42.

Date of initial receipt: 27 November 1995

Date of acceptance: 16 July 1996

Ms 155SR-208 


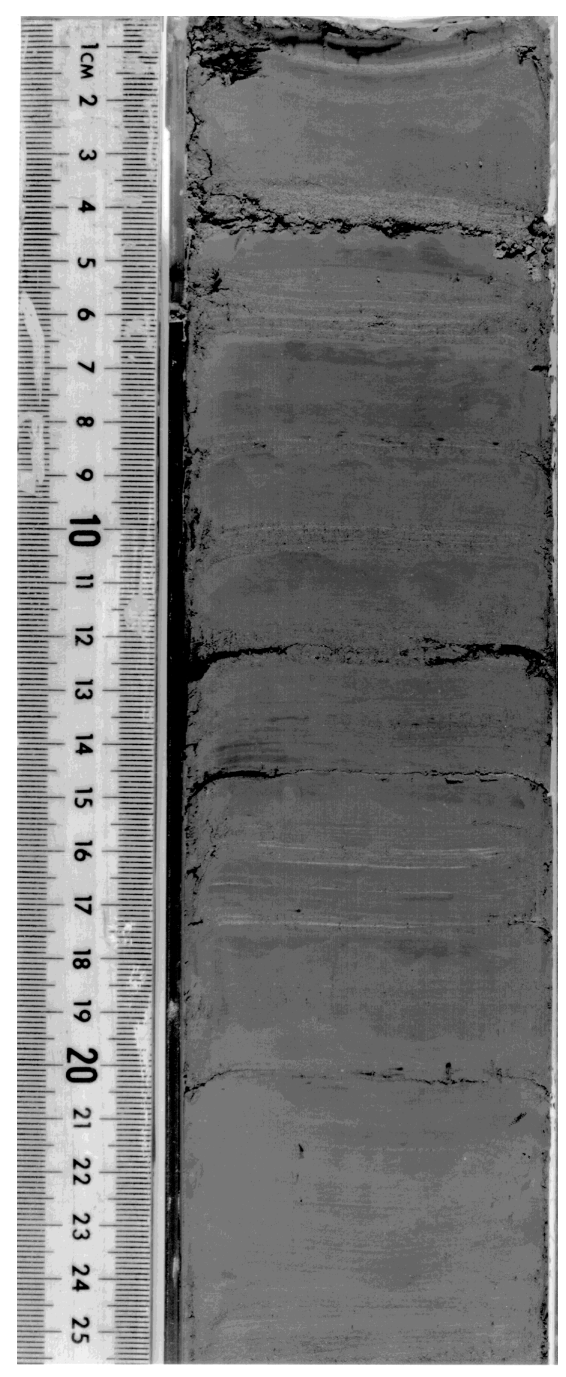

Core photograph

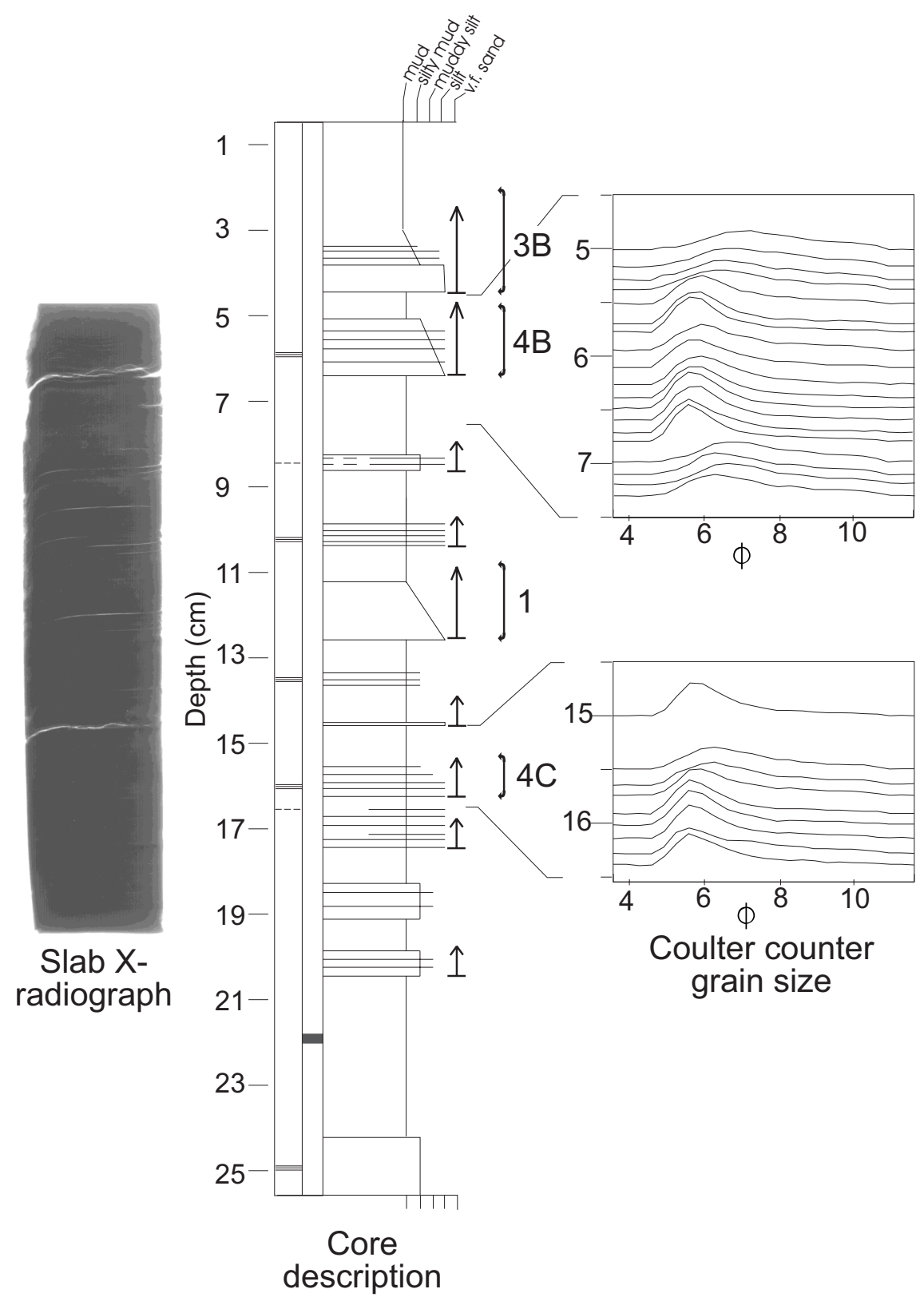

Figure 12. Example of Facies 1 fine-grained turbidite, thin graded sorted silt to mud bed, no silt laminae (Section 155-941A-15X-7). 

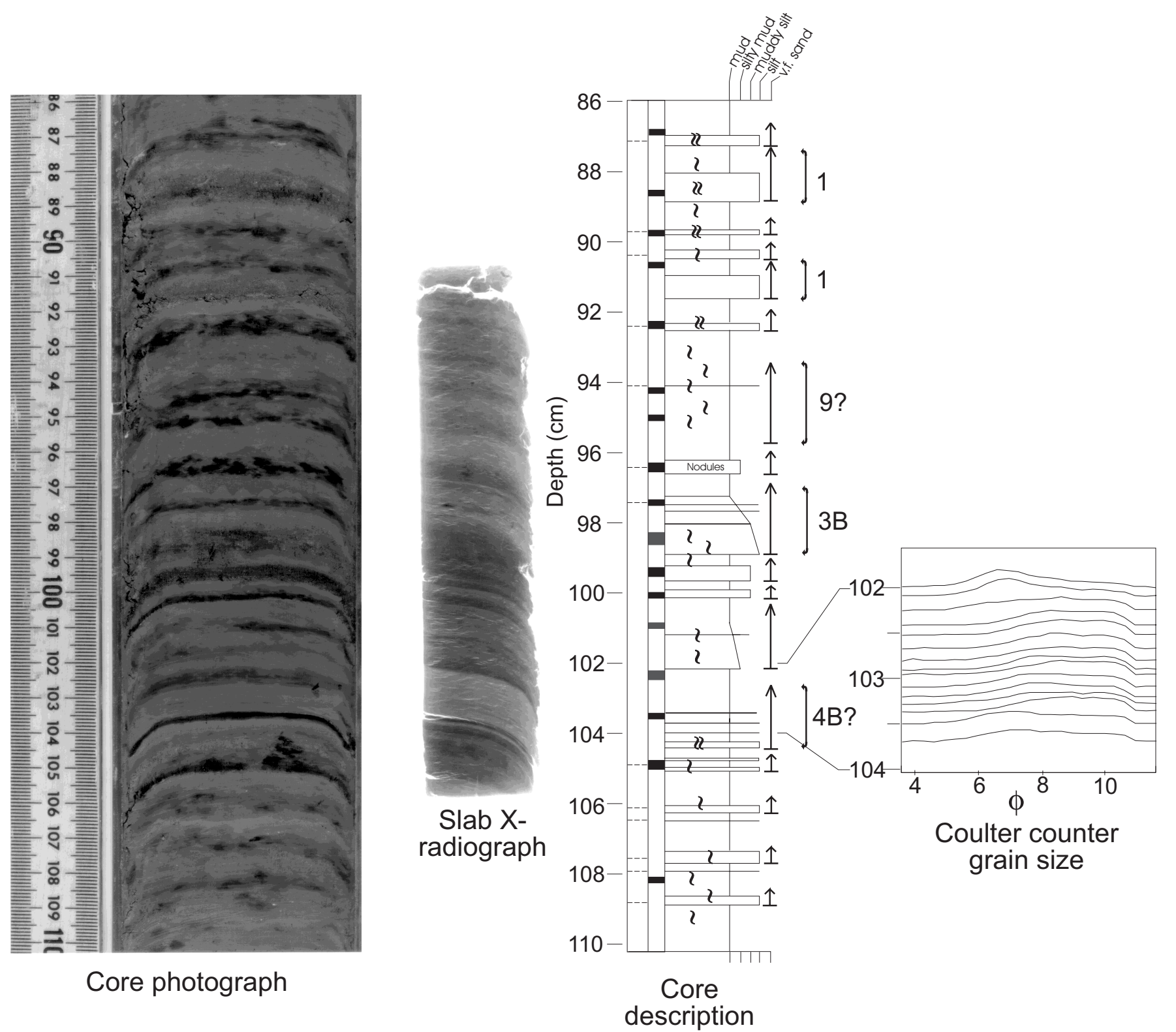

Figure 13. Example of Facies 1 fine-grained turbidite, thin graded sorted silt to mud bed, no silt laminae (Section 155-946A-7H-4). 


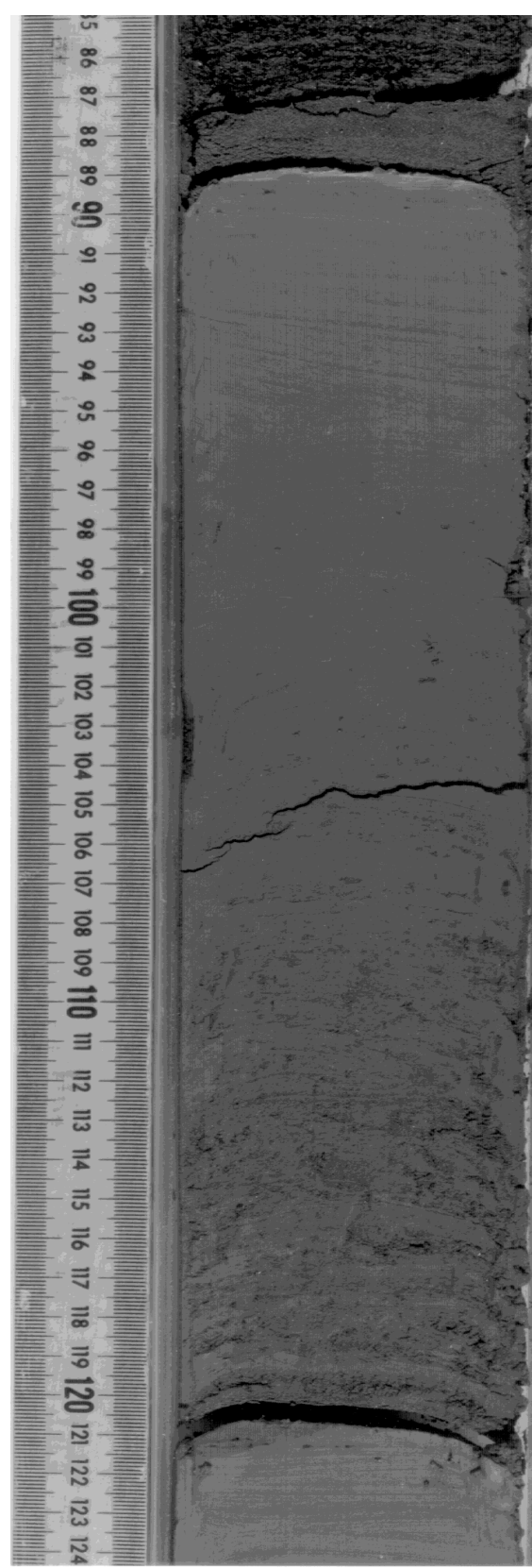

Core photograph

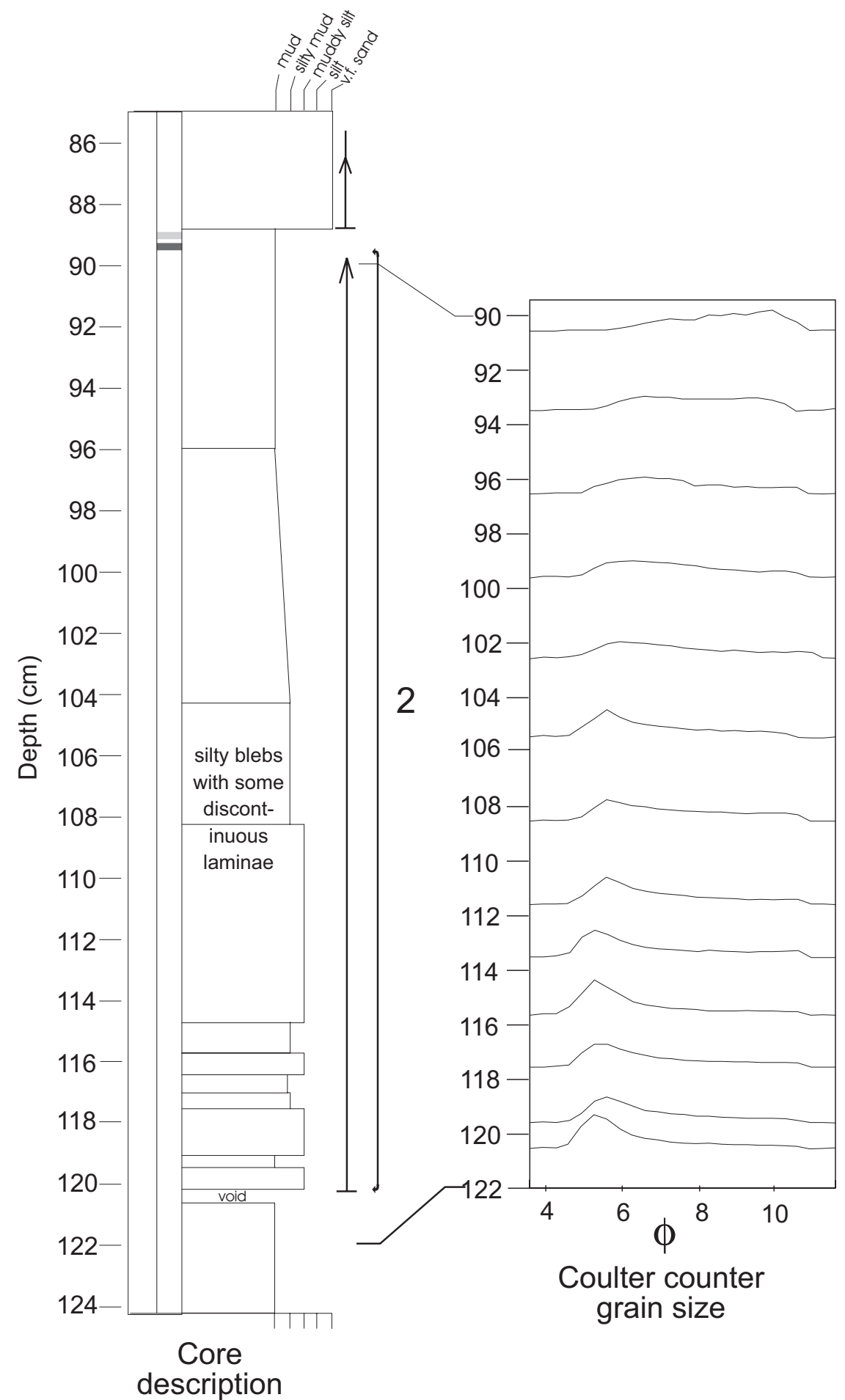

Figure 14. Type example of Facies 2 fine-grained turbidite, thick silty mud turbidite with blebs of sand at the base (Section 155-934B-4H-3). 


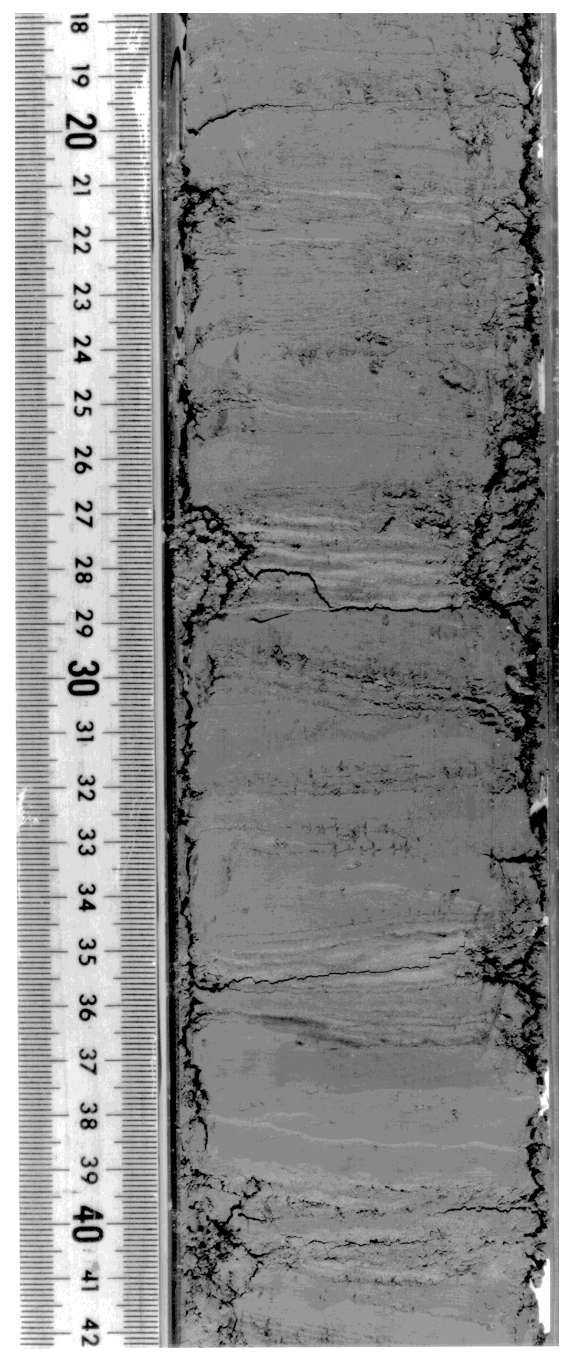

Core photograph

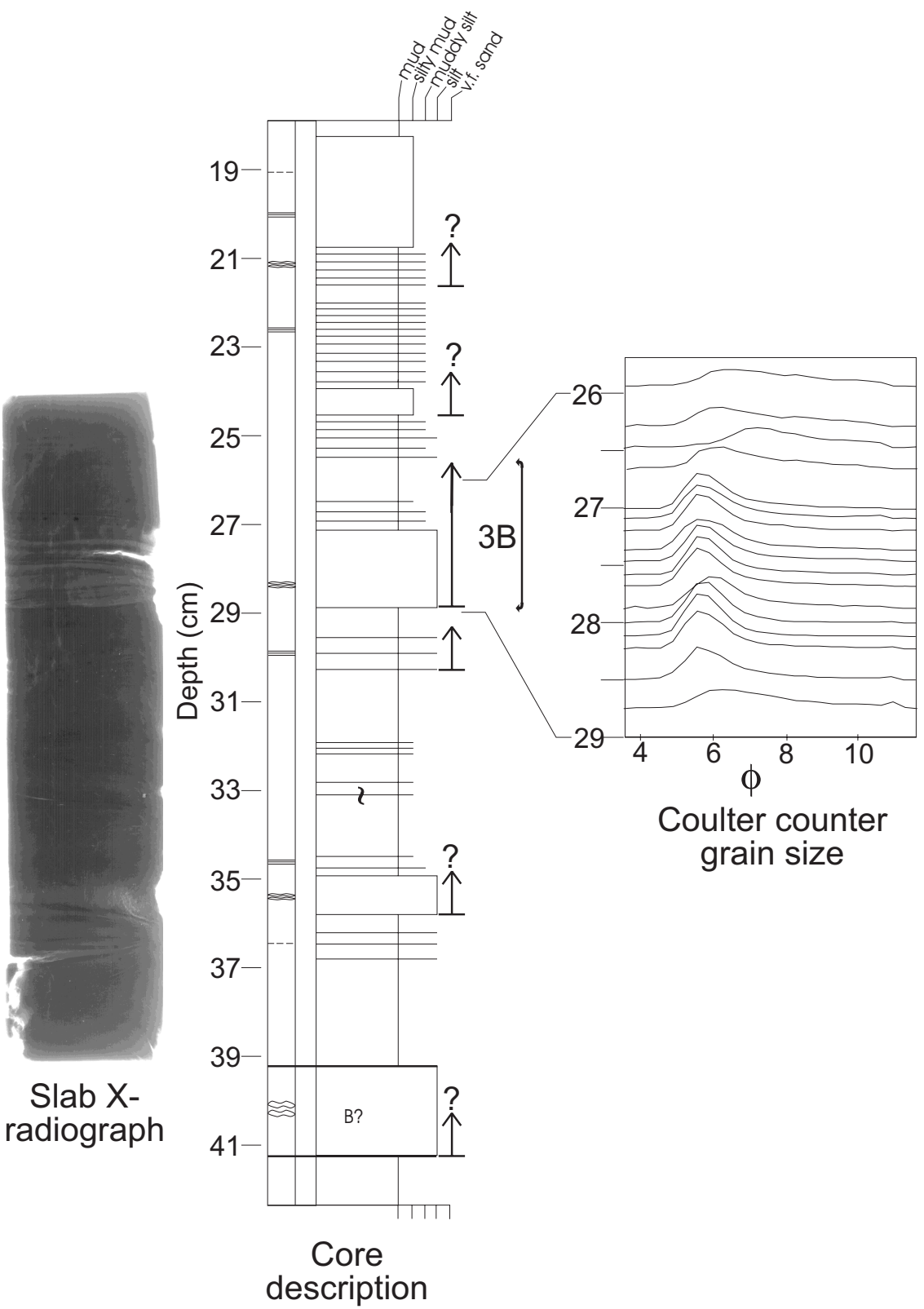

Figure 15. Type example of Facies 3B fine-grained turbidite, sorted silt bed grading into mud with rare silty laminae (Section 155-930C-11X-2). 


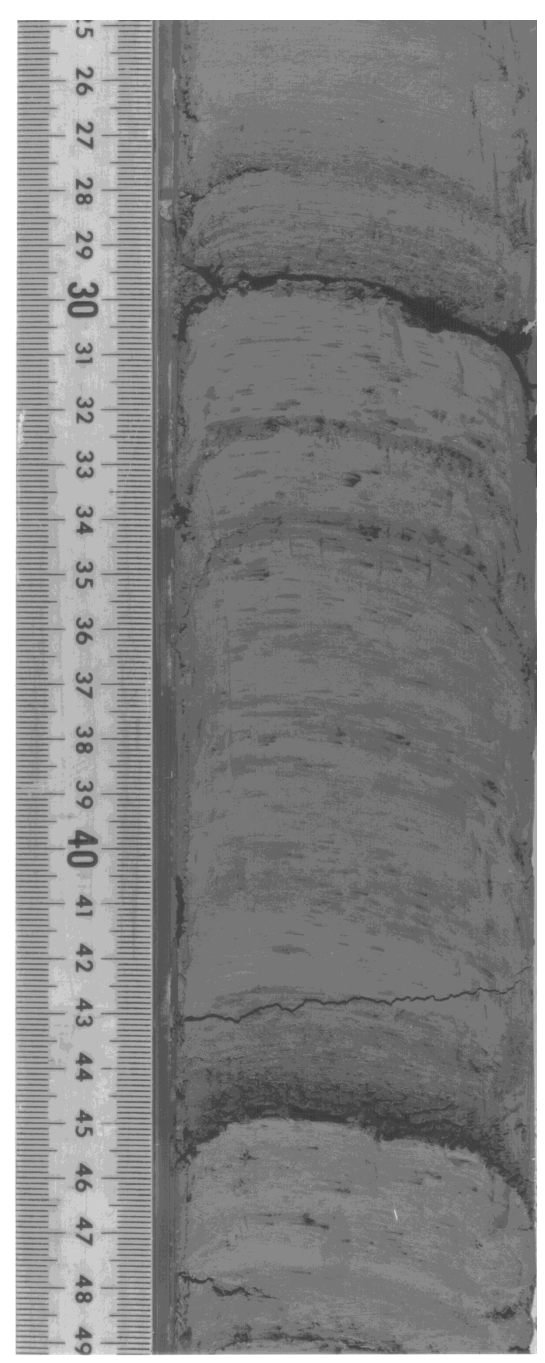

Core photograph

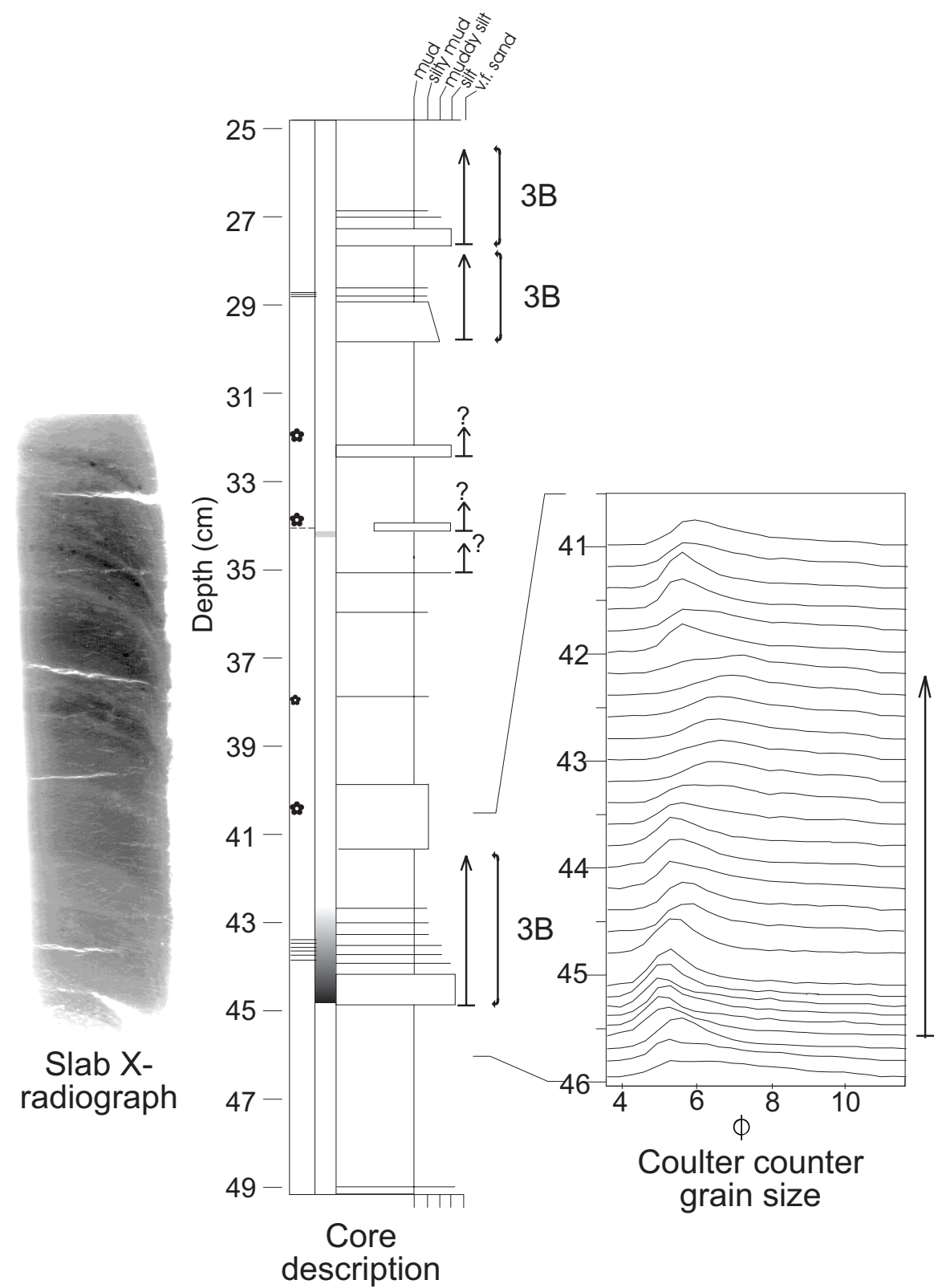

Figure 16. Example of Facies 3B fine-grained turbidite, sorted silt bed grading into mud with rare silty laminae (Section 155-937B-8H-2). 


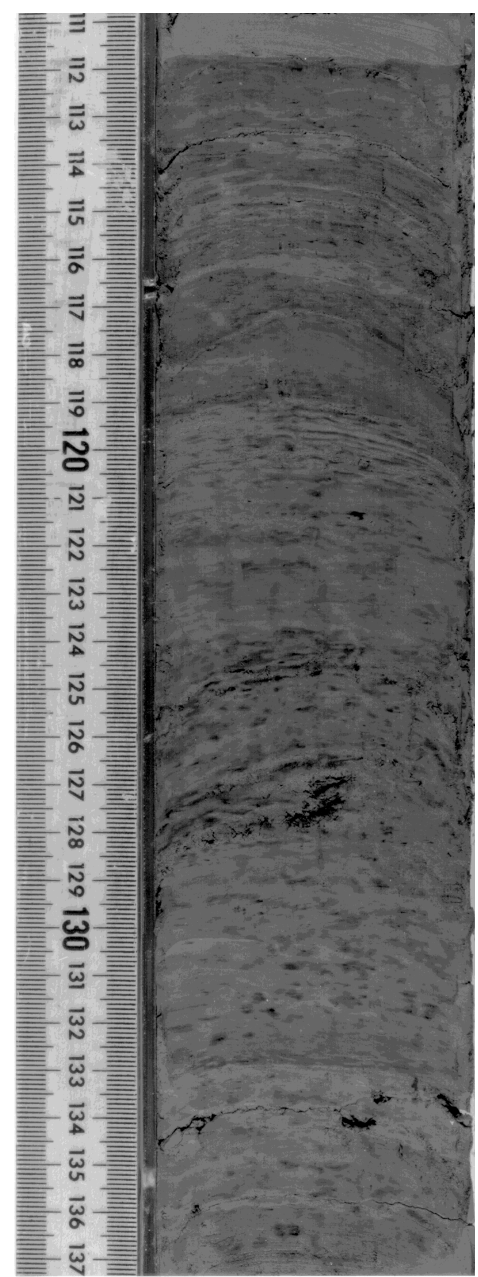

Core photograph
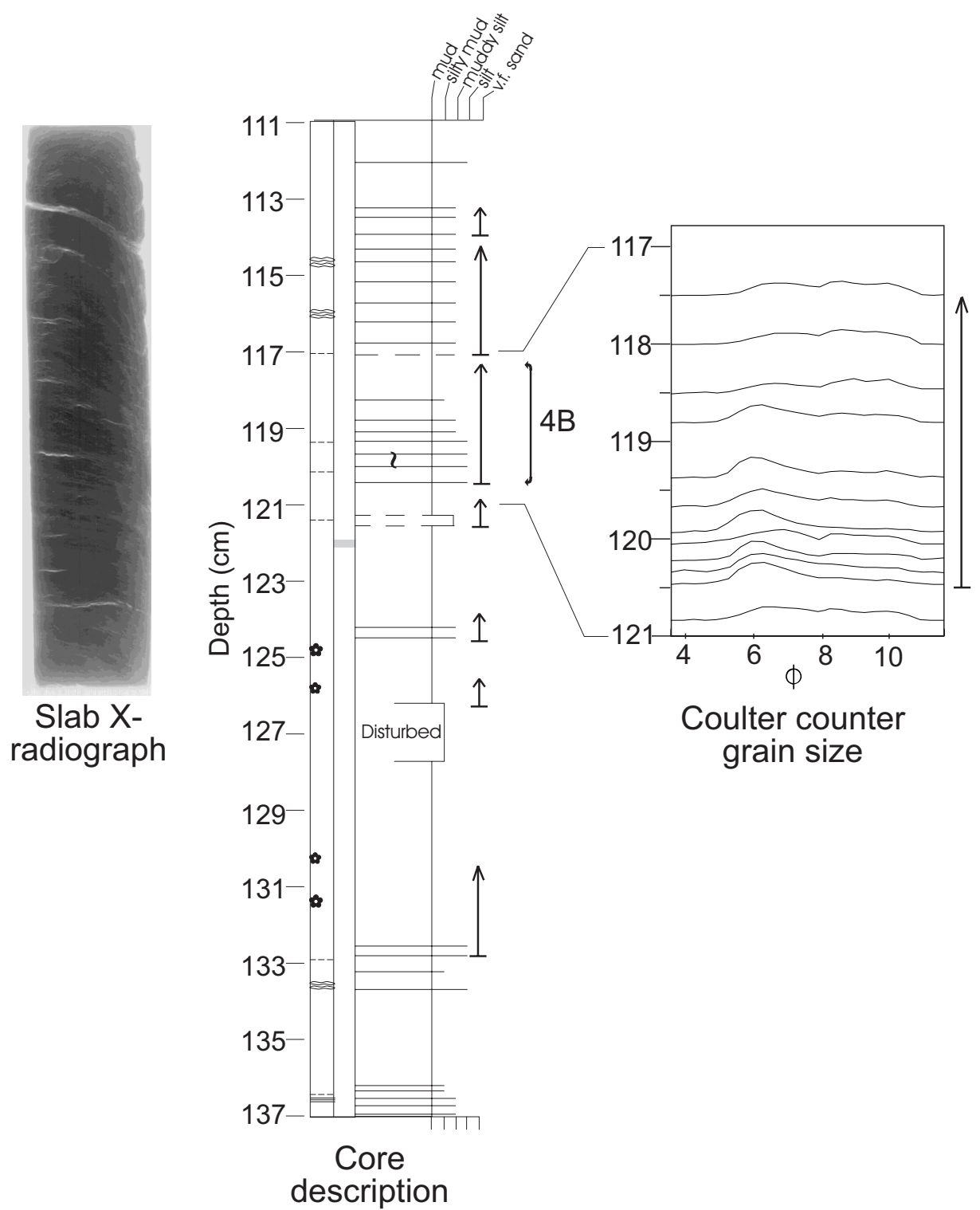

Figure 17. Type example of Facies 4B fine-grained turbidite, poorly defined $T_{d}$ silt/mud laminae grading up in to mud (Section 155-936A-6H-2). 


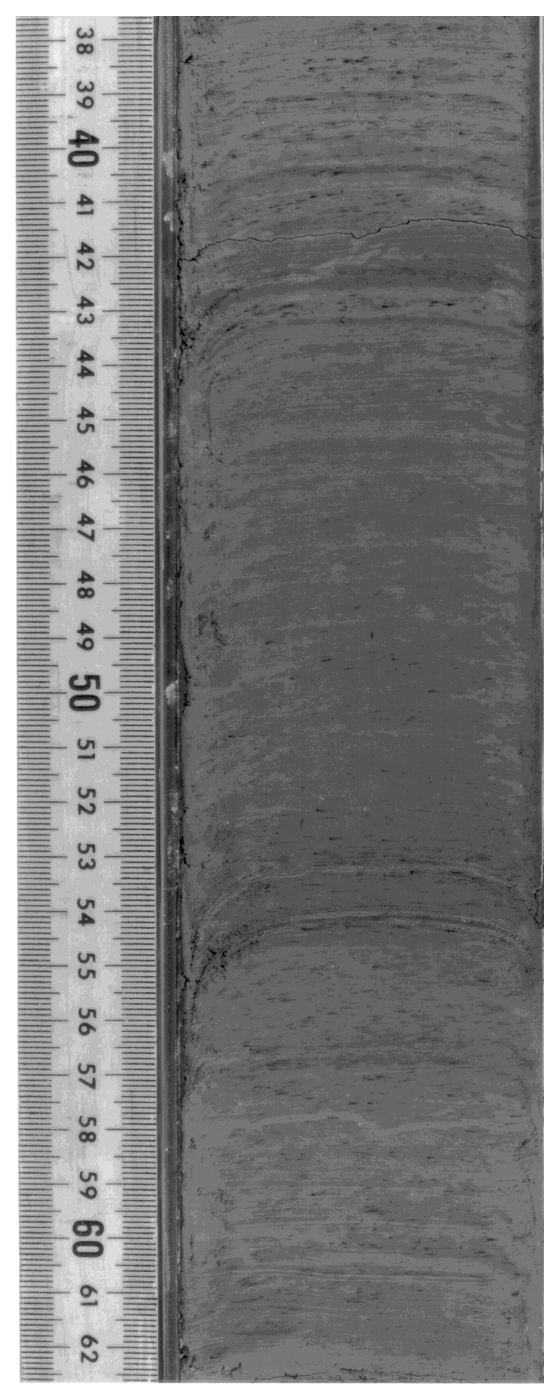

Core photograph

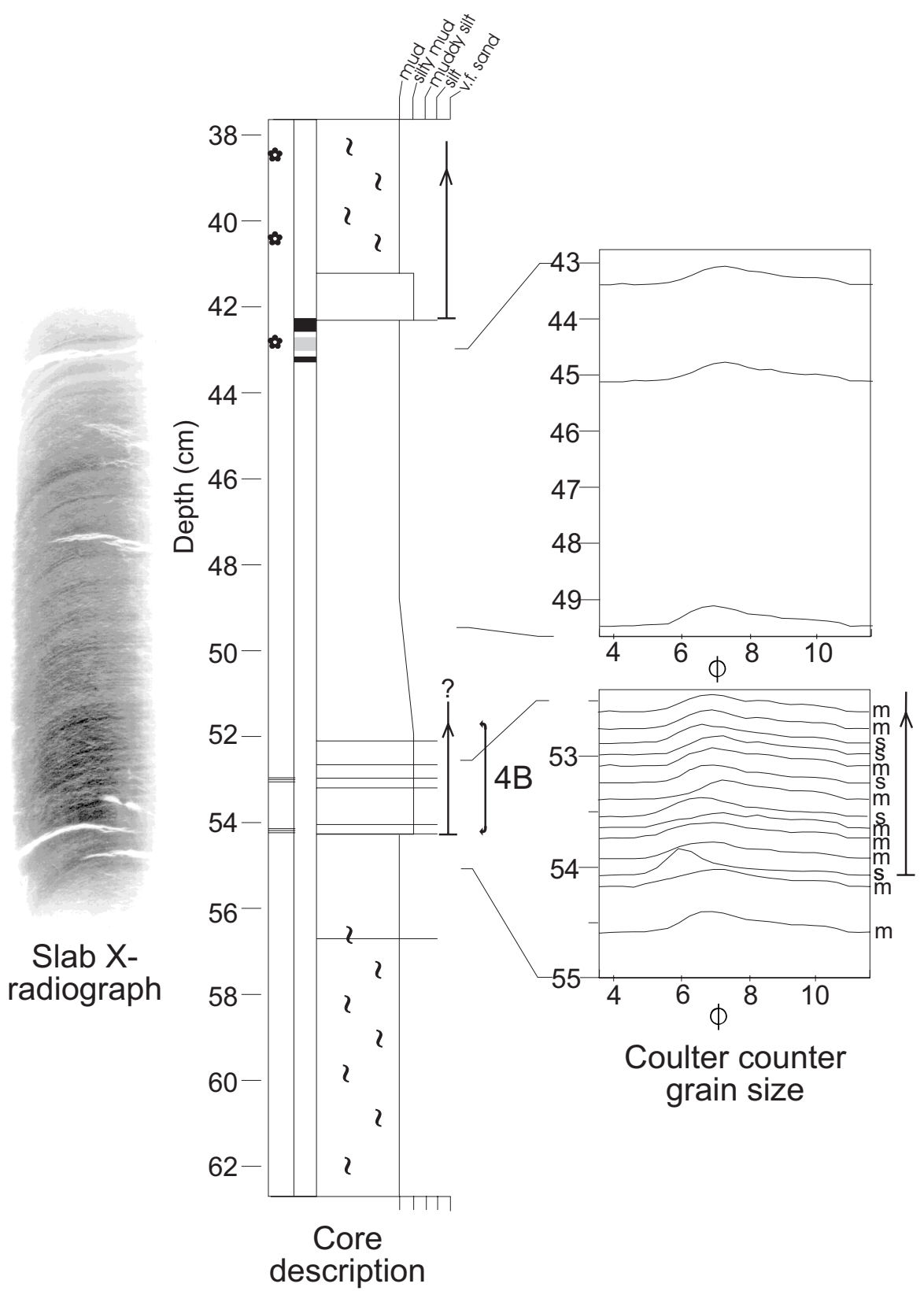

Figure 18. Example of Facies 4B fine-grained turbidite, poorly defined $T_{d}$ silt/mud laminae grading up in to mud (Section 155-944D-4H-4). 

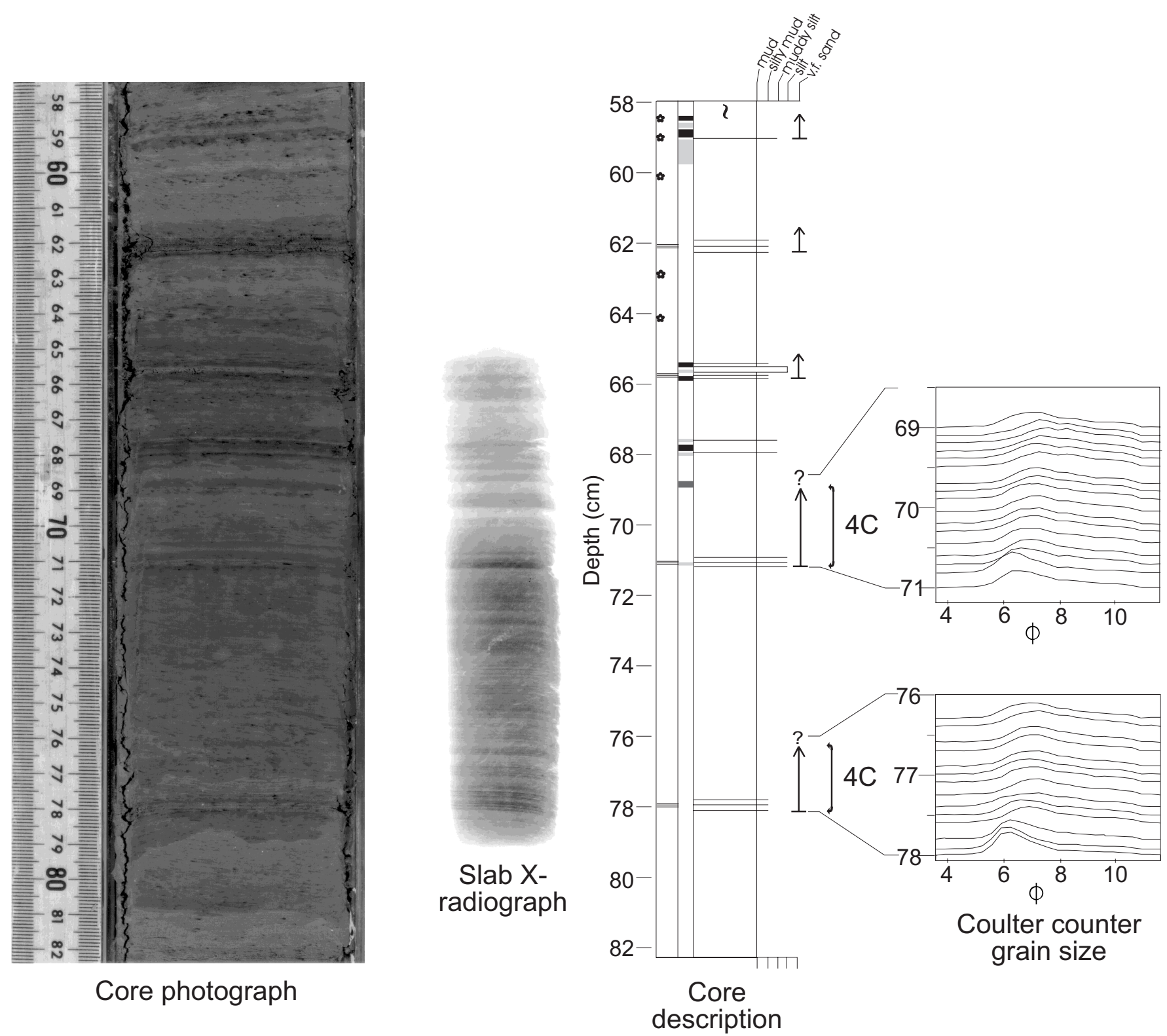

Figure 19. Type example of Facies $4 \mathrm{C}$ fine-grained turbidite, very fine $\mathrm{T}_{\mathrm{d}}$ silt/mud laminae grading up into mud (Section 155-944D-3H-1). 


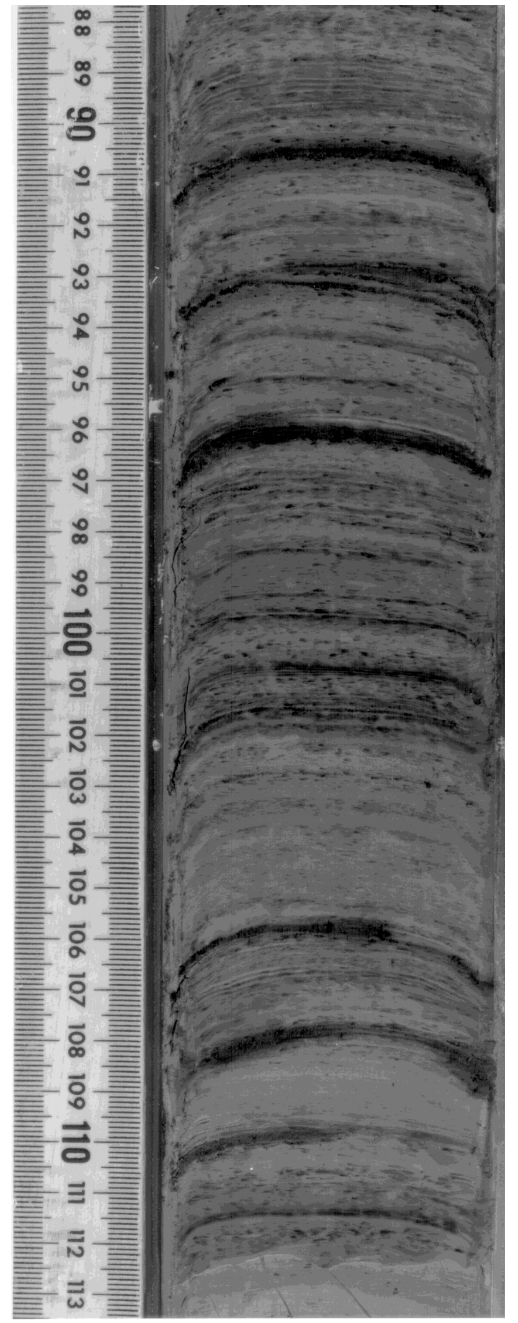

Core photograph
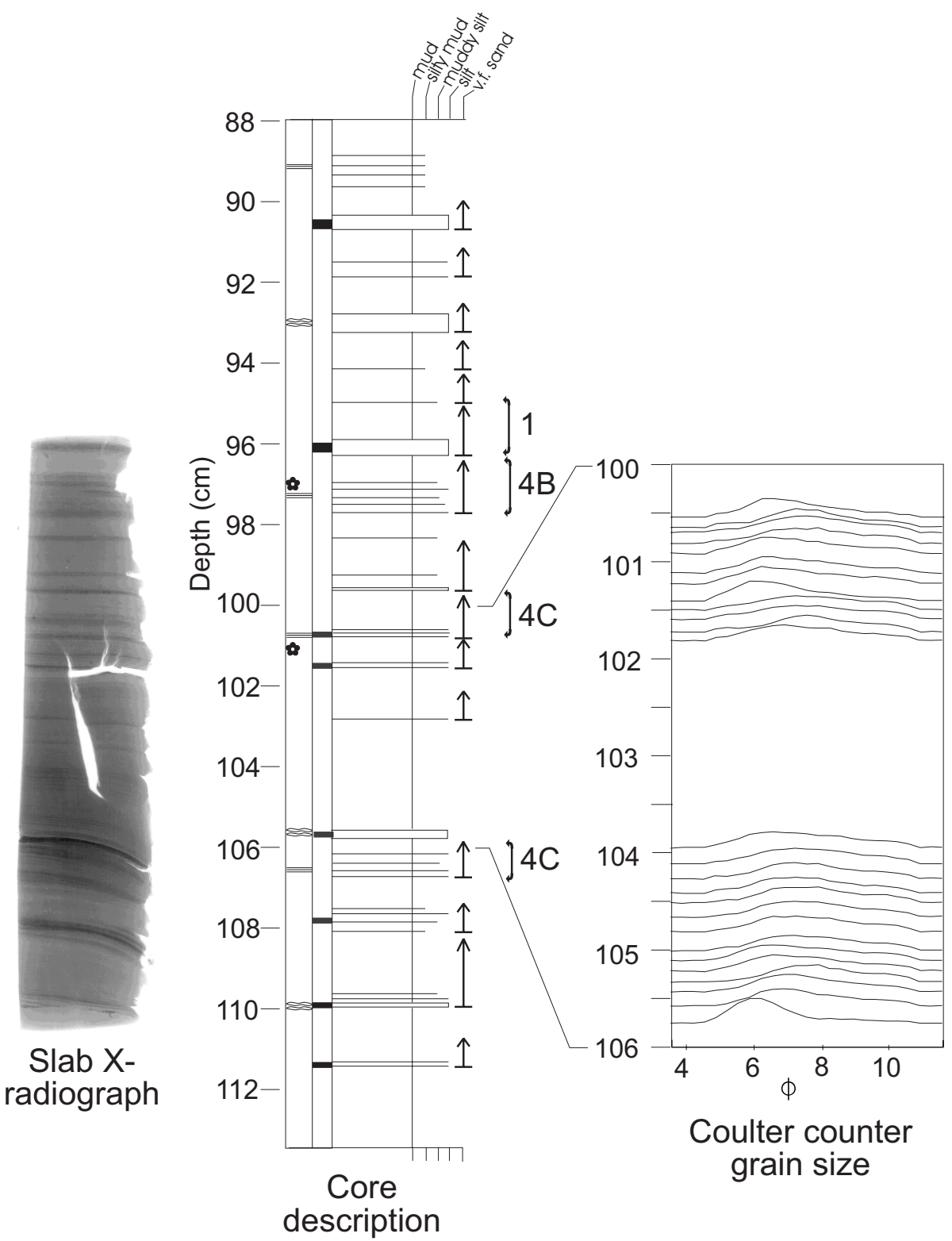

Figure 20. Example of Facies $4 \mathrm{C}$ fine-grained turbidite, very fine $T_{d}$ silt/mud laminae grading up into mud (Section 155-940A-3H-4). 


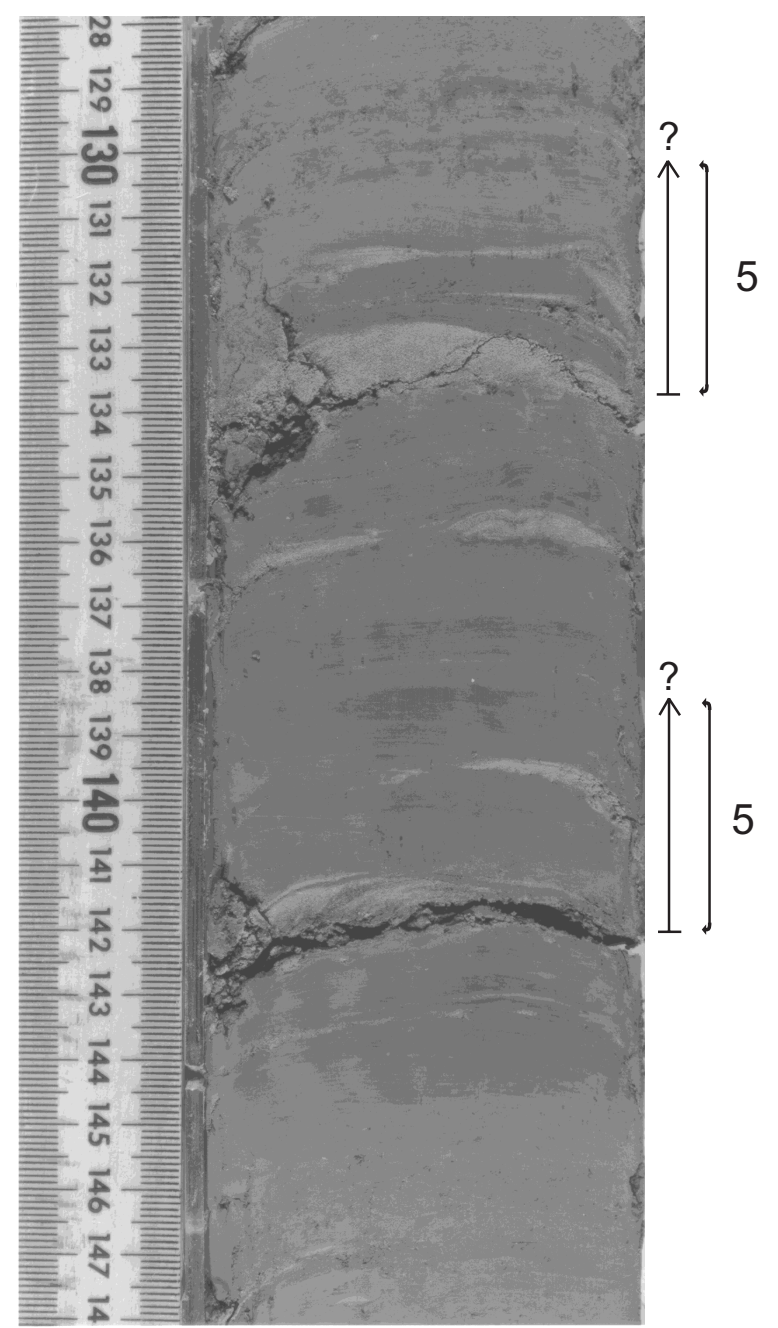

Figure 21. Type example of Facies 5 fine-grained turbidite, mud bed with starved silt ripples and thick lenticular silt laminae (Section 155-935A-8H-4).

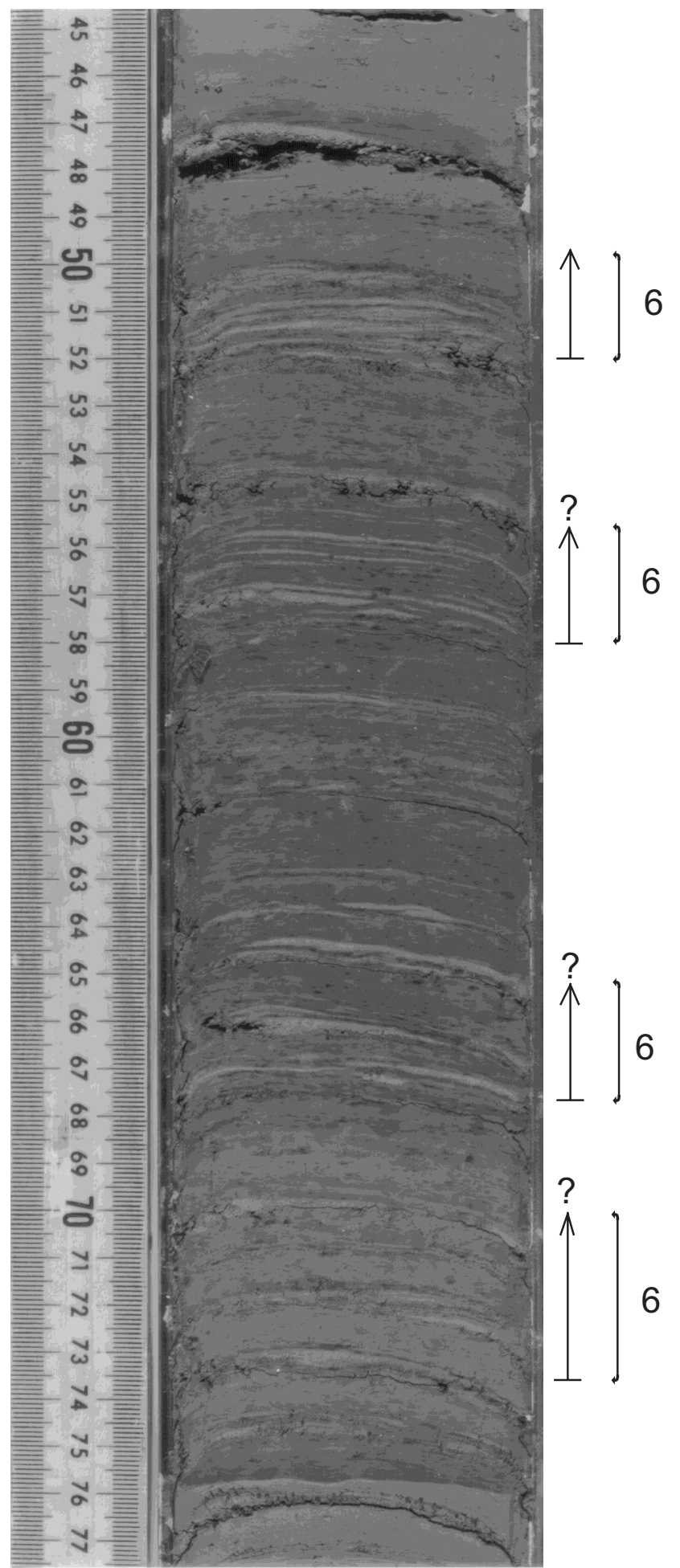

Figure 22. Type example of Facies 6 fine-grained turbidite, mud bed with groups of thin, lenticular silt laminae (Section 155-940A-6H-6). 

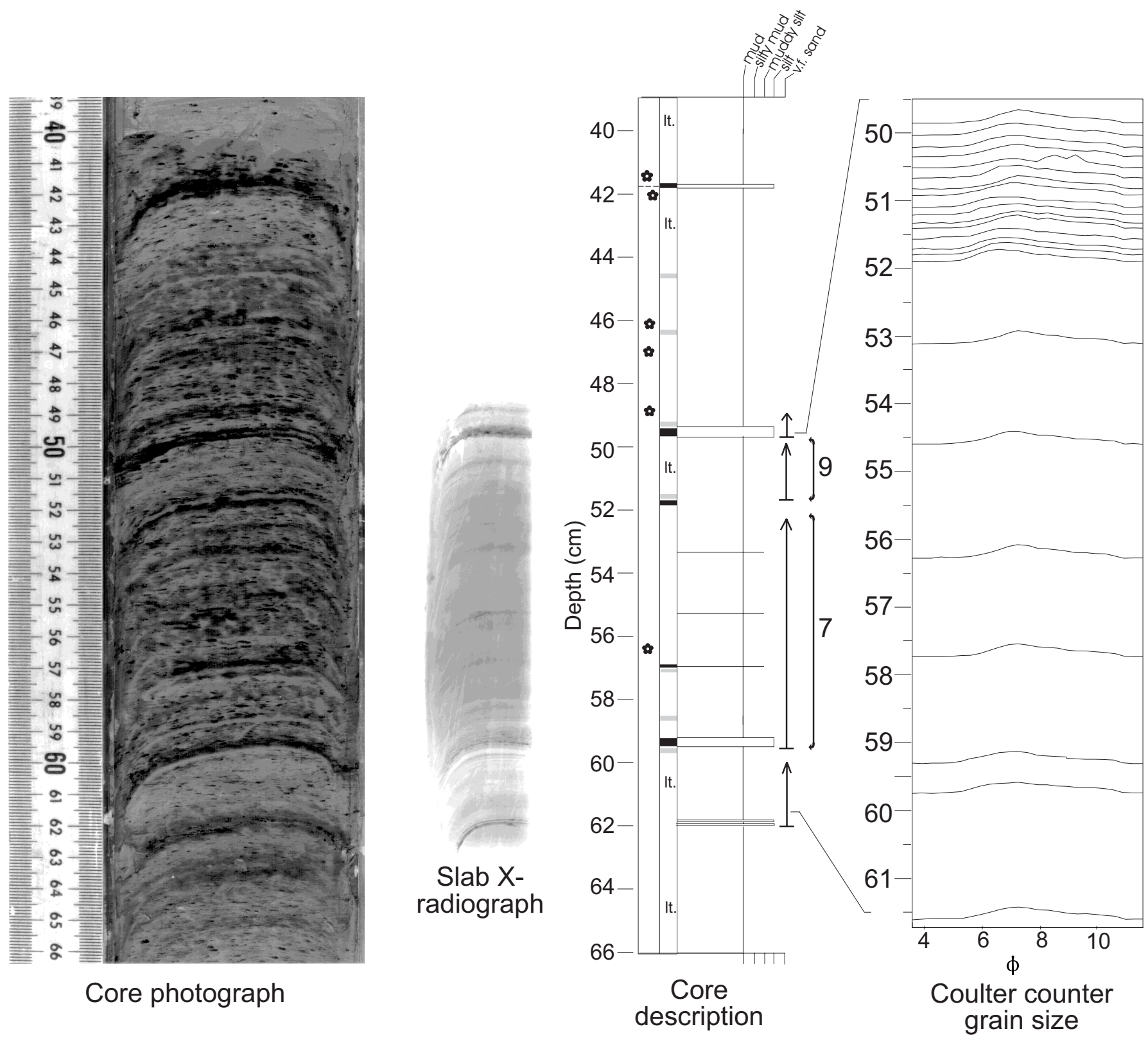

Figure 23. Example of Facies 7 fine-grained turbidite, mud turbidite with basal silt lamina (Section 155-940A-2H-5). 


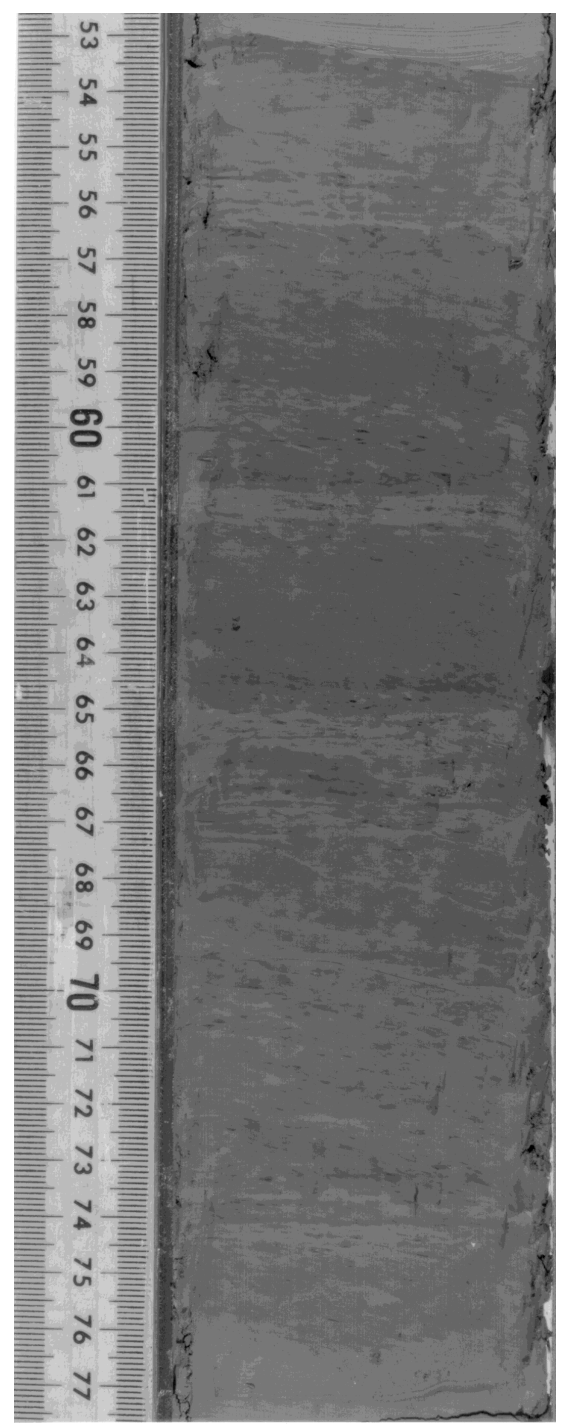

Core photograph

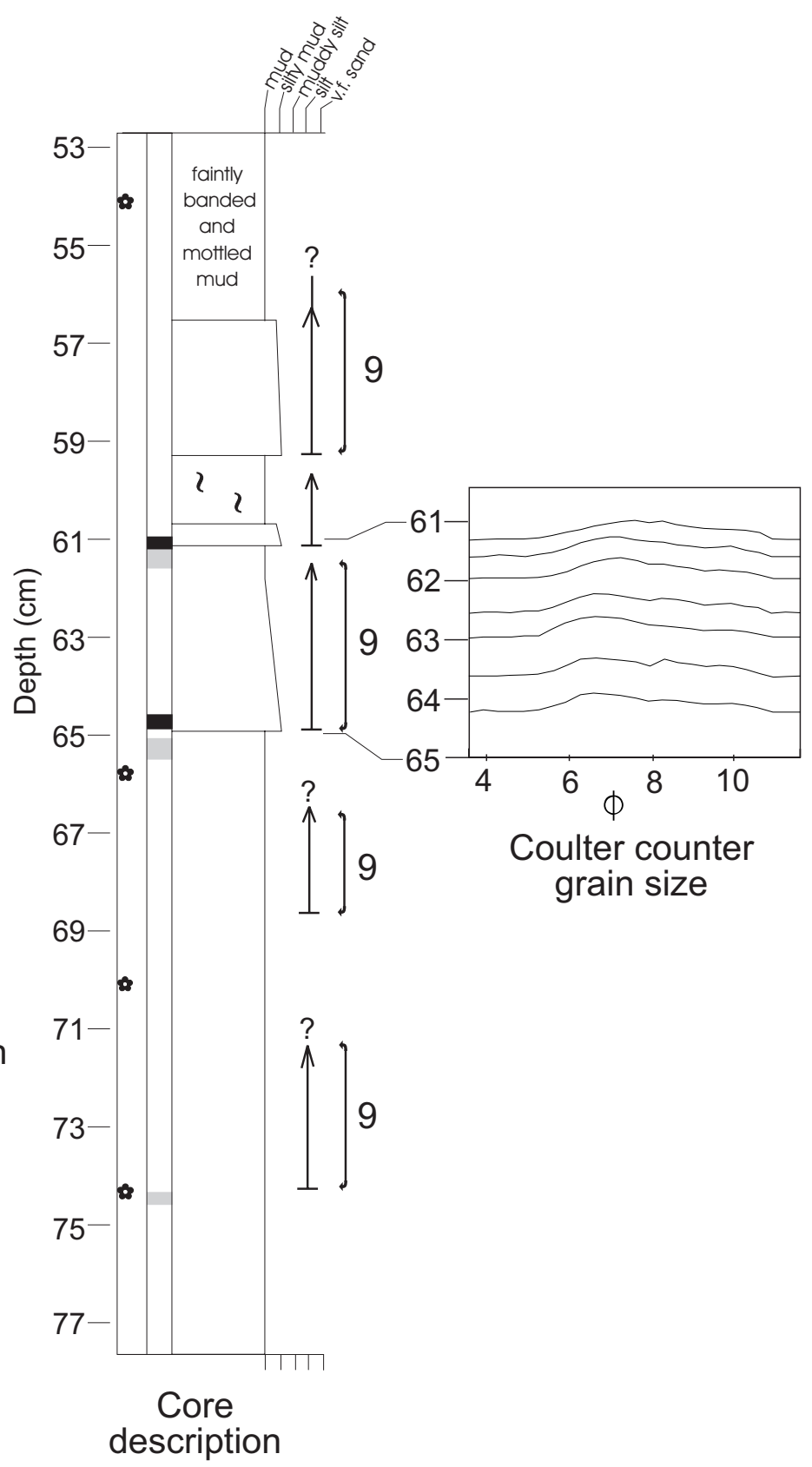

Figure 24. Type example of Facies 9 fine-grained turbidite, mud turbidite lacking basal silt lamina. (Section 155-935A-32X-4). 

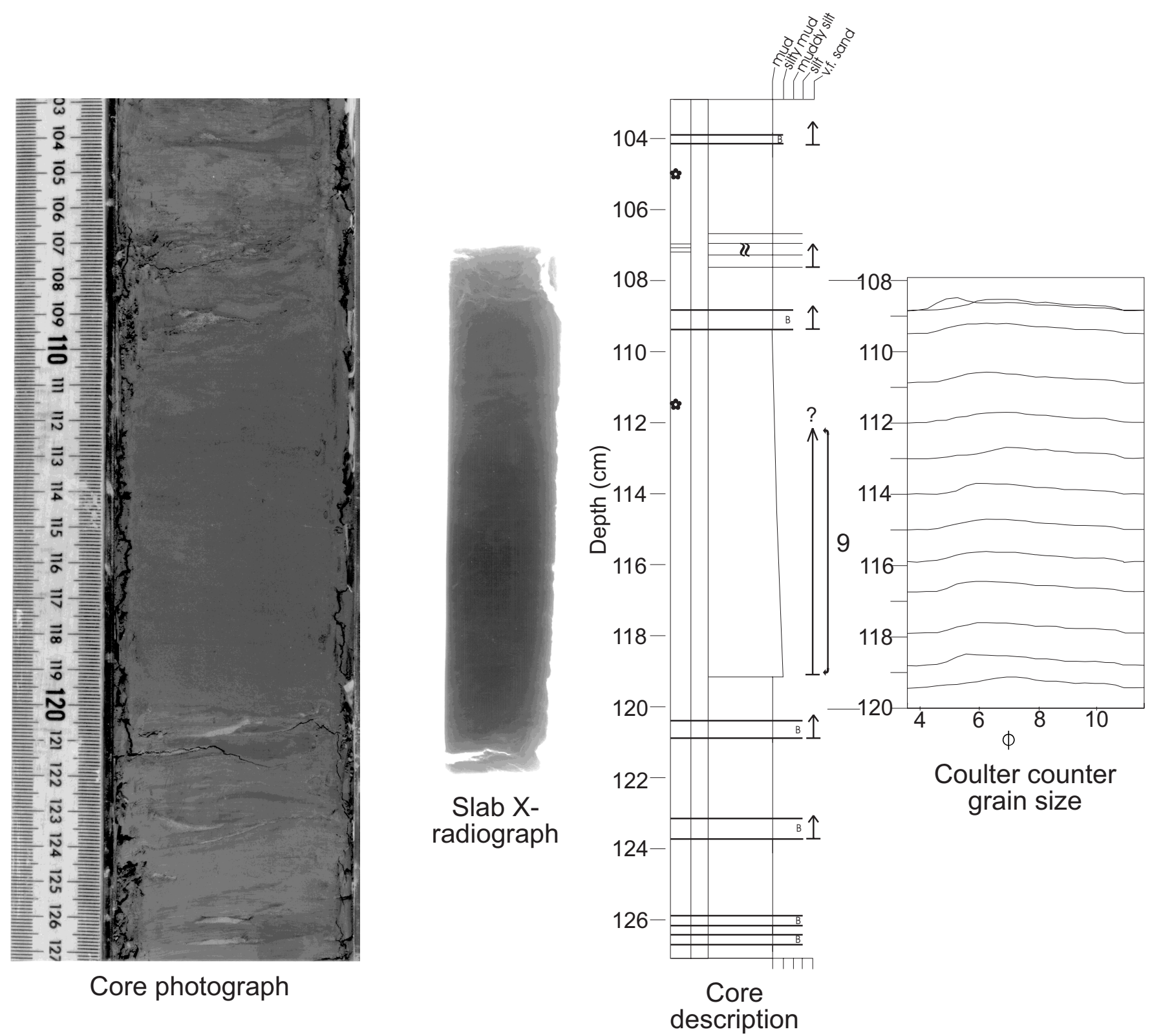

Figure 25. Example of Facies 9 fine-grained turbidite, mud turbidite lacking basal silt lamina (Section 155-940A-21X-2). 


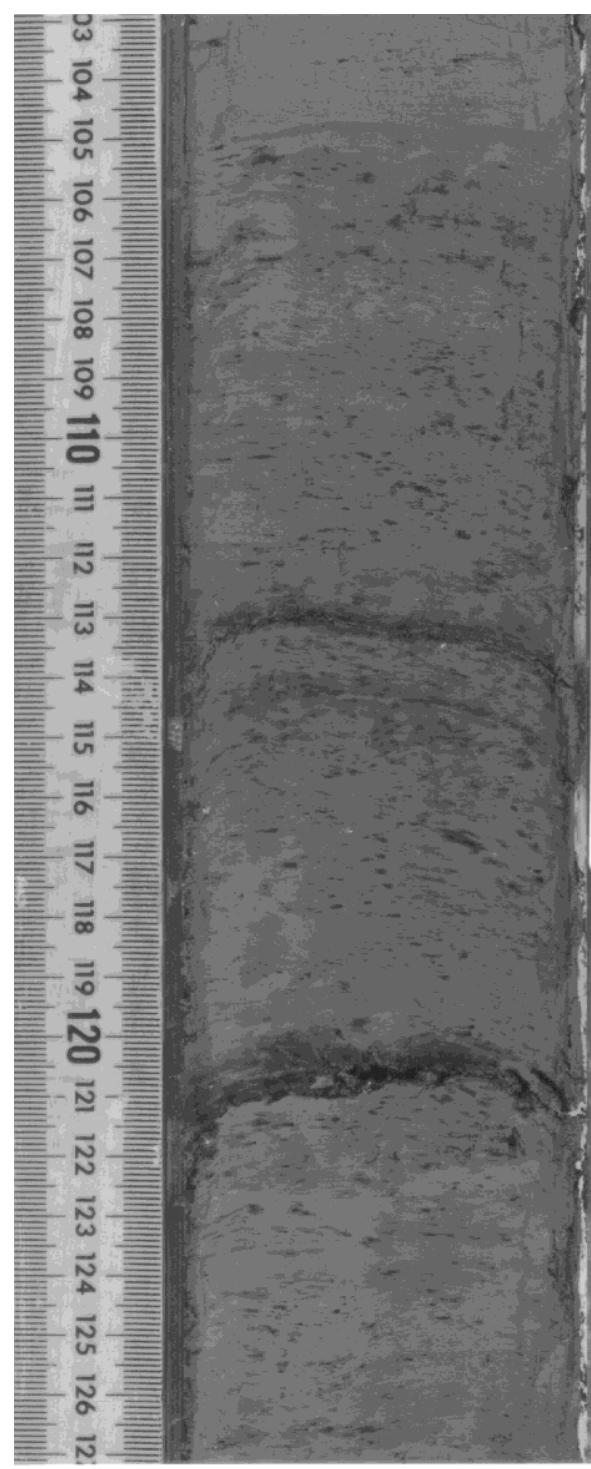

Core photograph

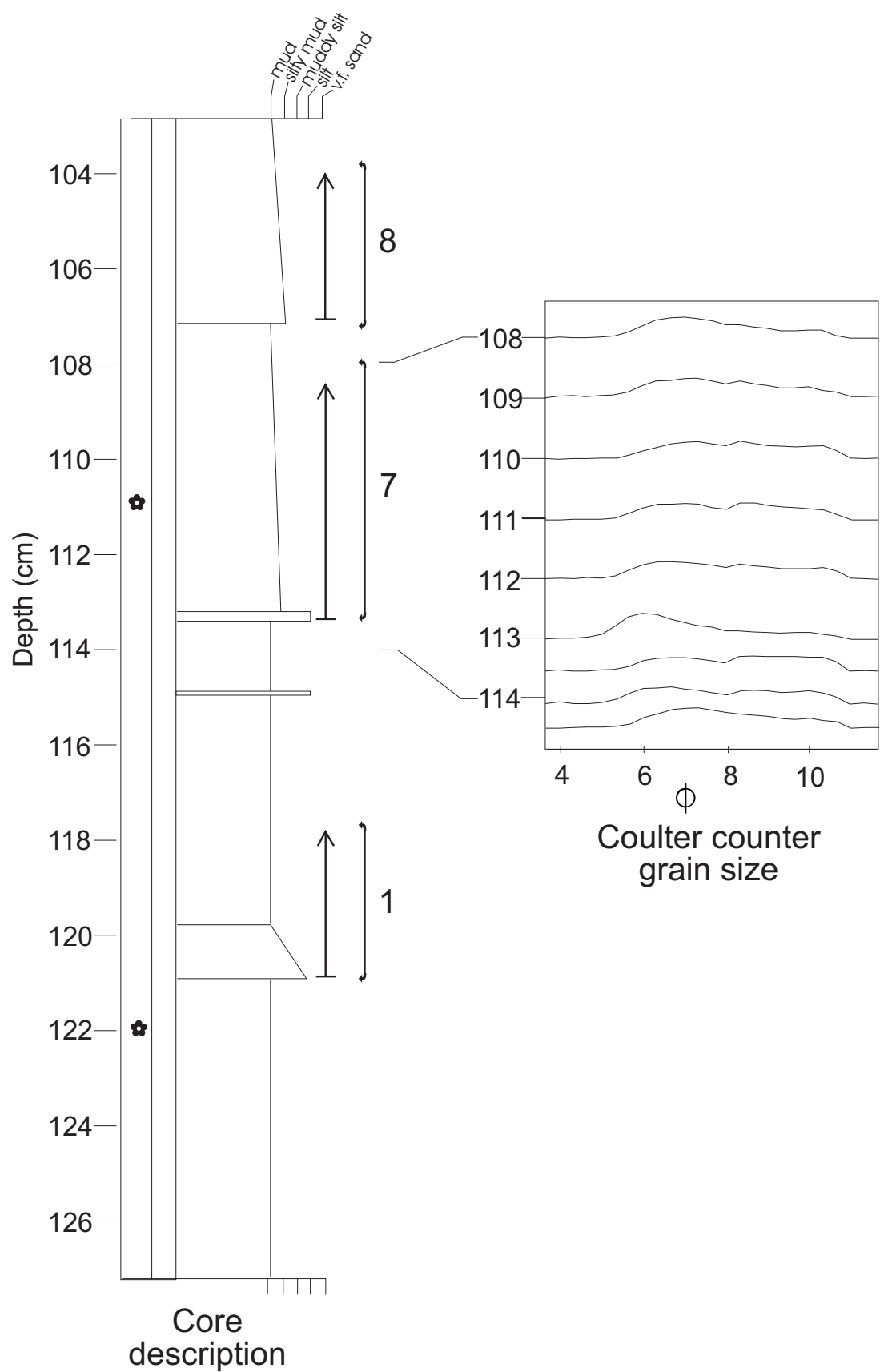

Figure 26. Example of Facies 9 fine-grained turbidite, mud turbidite lacking basal silt lamina (Section 155-939B-5H-1). 
Figure 27. Map showing average modal grain size of silt samples and mud samples analyzed by the Coulter counter plotted against site.

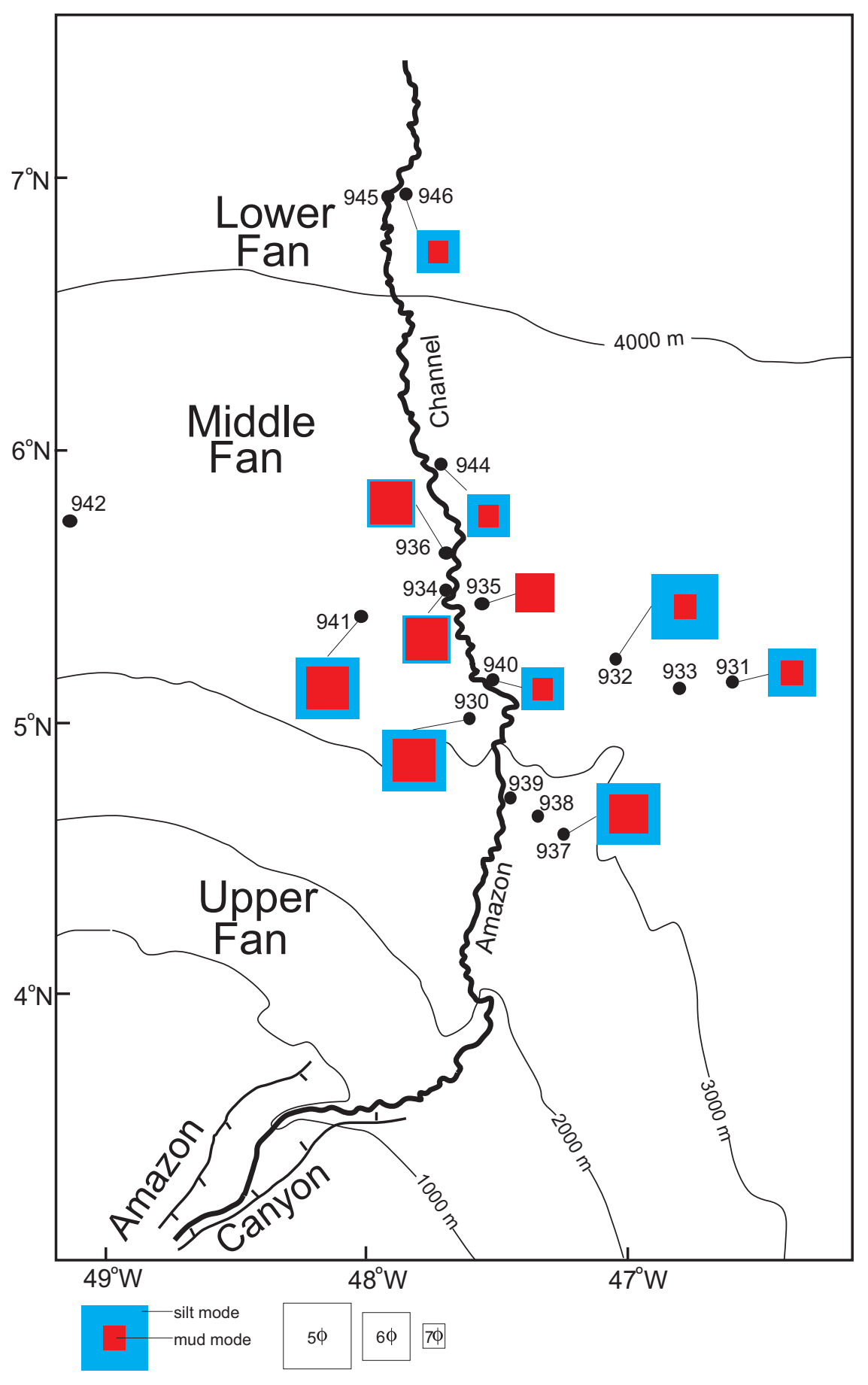




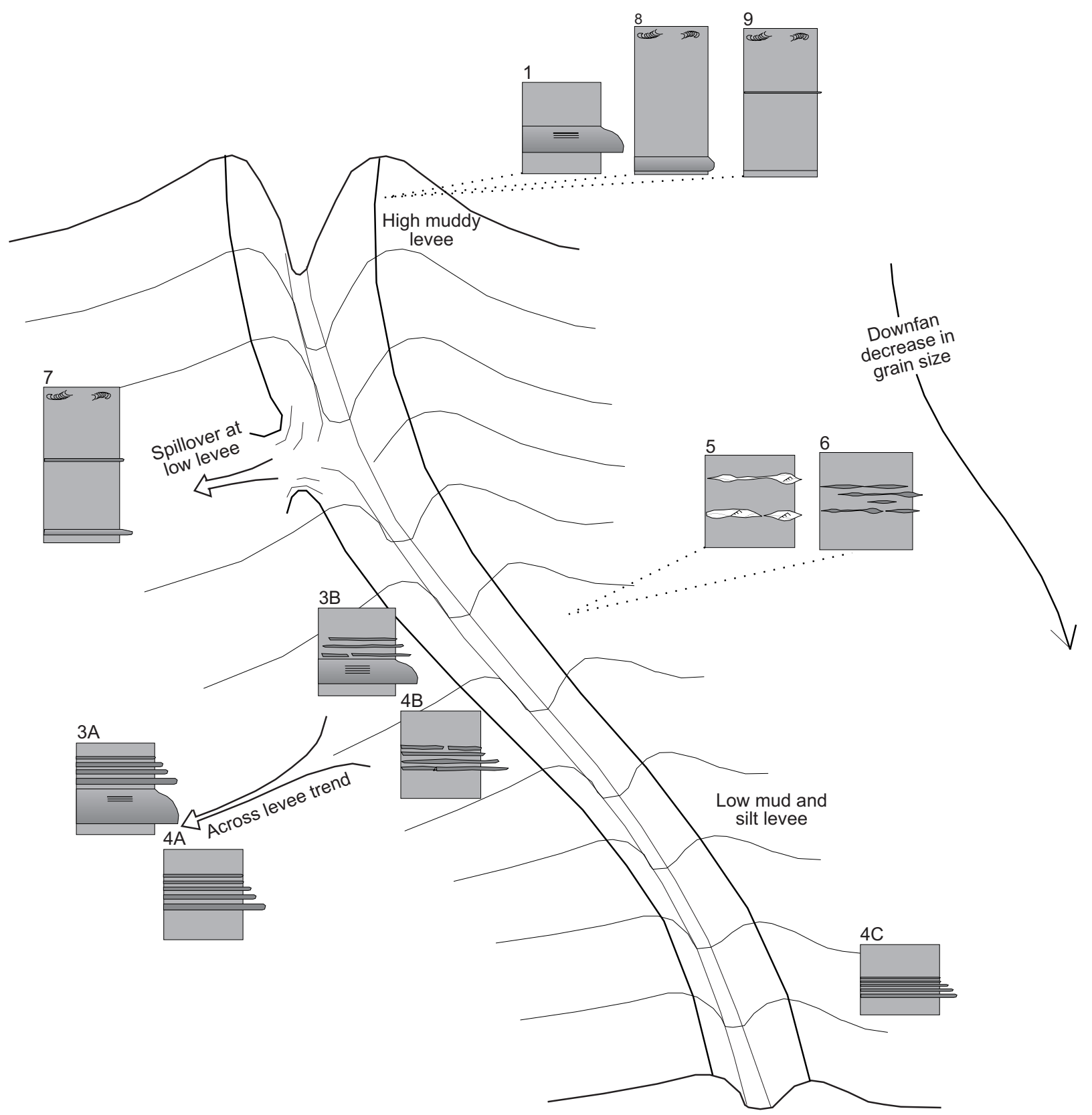

Figure 28. Schematic drawing of the probable relationship between seafloor morphology and the principal types of fine-grained turbidites recognized on the Amazon Fan. 


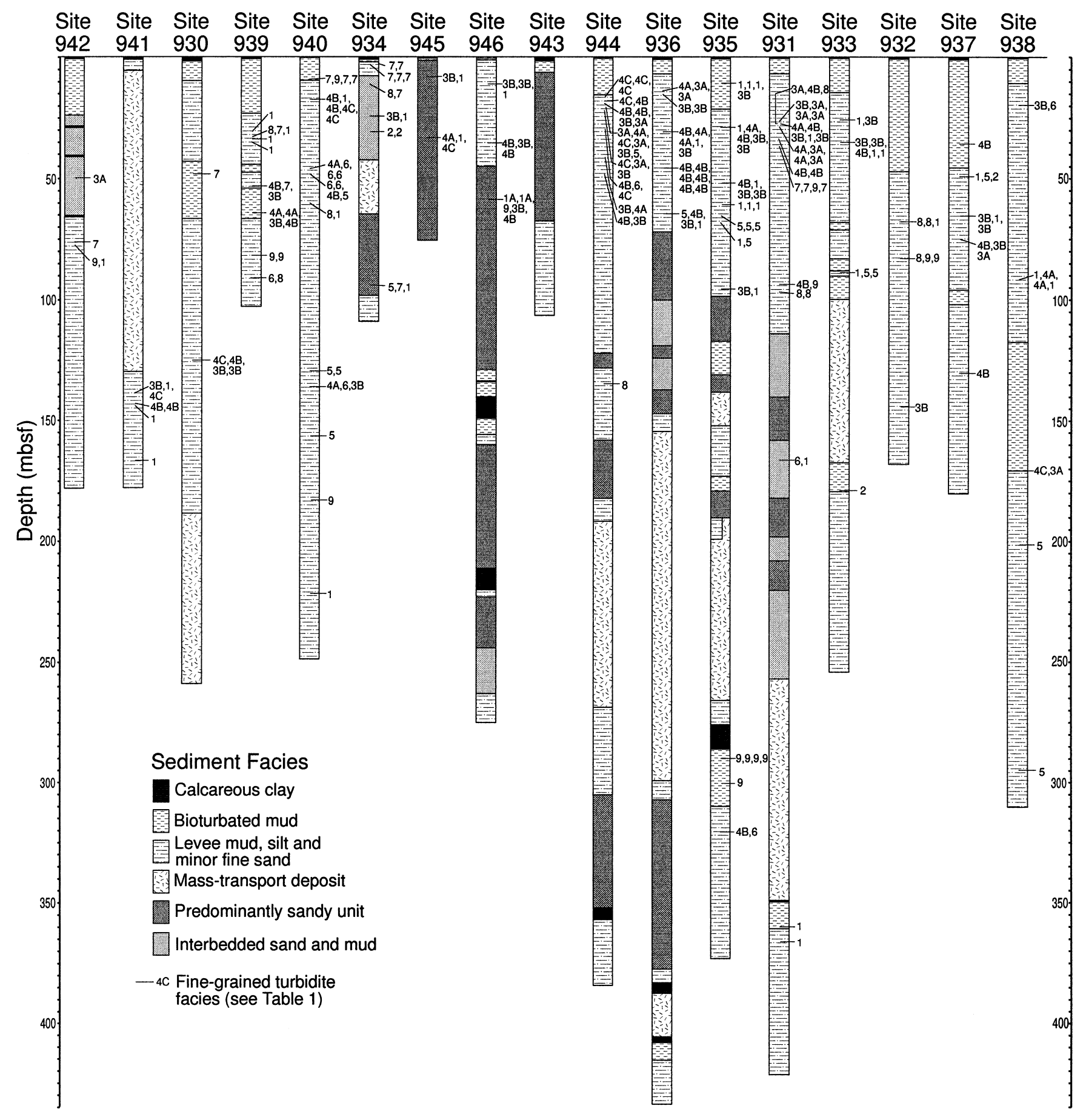

Figure 29. Summary stratigraphic columns showing location of identified fine-grained turbidite facies. 